\title{
First avifaunal survey of a Cerrado dry forest enclave on the right bank of the São Francisco River, Minas Gerais, Brazil, with insights on geographic variation of some species
}

\author{
Marcelo Ferreira de Vasconcelos ${ }^{1,2,4}$ \& Santos D'Angelo Neto ${ }^{3}$ \\ 1 Pontifícia Universidade Católica de Minas Gerais (PUC-MINAS), Museu de Ciências Naturais (MCN). Belo Horizonte, MG, Brasil. \\ 2 Instituto Prístino. Belo Horizonte, MG, Brasil. \\ 3 Universidade Estadual de Montes Claros (UNIMONTES), Departamento de Biologia Geral. Montes Claros, MG, Brasil. \\ E-mail: santosdangelo@gmail.com \\ ${ }^{4}$ ORCID: 0000-0003-4146-8198. E-mail: mfvasconcelos@gmail.com (corresponding author)
}

\begin{abstract}
Cerrado dry forest enclaves have been treated as an endemic bird area. In the last years, some avifaunal surveys have been conducted in dry forests on the left bank of the São Francisco River, eastern Brazil. Nevertheless, there is a gap of detailed ornithological surveys in the Cerrado dry forest enclaves on the right bank of this river. Here, we present the first avifaunal survey of a Cerrado dry forest enclave on the right bank of the São Francisco River. The study area, named "Curral de Pedras", comprises a dry forest enclave and other associated habitats in central Minas Gerais state, southeastern Brazil. We recorded 172 bird species; nine taxa have their ranges strongly associated to the Caatinga; six present their ranges associated to the Atlantic Forest and one is typical of the Cerrado. Important records are those of Campylopterus calcirupicola, a recently described species associated with dry forests of central Brazil, and Celeus ochraceus, collected in its southernmost range. Furthermore, we obtained specimens that present intermediate phenotypes between the following woodcreeper species: Lepidocolaptes squamatus / L. wagleri and Xiphocolaptes albicollis / X. falcirostris. Those records reinforce the need of further sampling and collecting activities in those dry forest enclaves aiming future researches in taxonomy, geographic variation, and phylogeography.
\end{abstract}

Key-Words. Birds; Cerrado; Seasonally dry tropical forests; Geographic variation.

\section{INTRODUCTION}

Seasonally dry tropical forests (hereafter SDTFs) present a circum-Amazonian distribution in South America and have been the main focus of many recent biogeographic and conservation studies (e.g., Prado \& Gibbs, 1993; Espírito-Santo et al., 2009; Pennington et al., 2000, 2006, 2009; Zanella, 2010; Werneck, 2011; Werneck et al., 2011; Santos et al., 2012; Arruda et al., 2013; DryFlor, 2016). These forests are usually associated with fertile soils and with climates marked by highly seasonal rainfall with a severe dry season of three to six months, when most of the vegetation is leafless (Pennington et al., 2006; DryFlor, 2016). SDTFs are patchily distributed in South America in several "nuclei" of which the Caatinga biogeographical province (sensu Morrone, 2014) of northeastern Brazil is the largest one (Prado \& Gibbs, 1993).

Small areas of SDTFs are also patchily distributed throughout the Cerrado (a biogeographic province predominantly covered by tropical savanna), usually associated to limestone outcrops and limestone derived soils (Rizzini, 1997). These "islands" were named "Cerrado dry forests" by Santos et al. (2012) and are very important from a biogeographical point of view, since they suggest historical connections among several SDTF nuclei (Werneck \& Colli, 2006).

Further, Cerrado dry forest enclaves have been treated as endemic bird areas (Silva, 1997; Stattersfield et al., 1998; Silva \& Bates, 2002). Despite some problems of delimitation of these areas of endemism (see Silva et al. [2004] and Lopes [2009]), three species appear to be closely associated to these enclaves: Pyrrhura pfrimeri (Pfrimer's Parakeet), Knipolegus franciscanus (Caatinga Black-Tyrant), and the recently described Campylopterus calcirupicola (Dry-forest Sabrewing) (Pinto, 1952; Mattos et al., 1991; Willis \& Oniki, 1991; Silva \& Oren, 1992; Olmos et al., 1997; Lima, 1999; Kirwan et al., 2001, 2004; Pacheco \& Olmos, 2006; Vasconcelos et al., 2006; Olmos, 2008; Lopes et al., 2010; Rego et al., 2011; Dornelas et al., 2012; Mazzoni et al., 2015; Lopes et al., 2017). Olmos (2005) also included Lepidocolaptes wagleri (Wagler's Woodcreeper) as an endemic of these dry forests. Another species, 
Phylloscartes roquettei (Minas Gerais Tyrannulet), was considered endemic to these dry forests (Stattersfield et al., 1998; Olmos, 2005), but it has been recently recorded in gallery forests and arboreal caatingas, a deciduous forest occurring along the hinterland borders of the Caatinga province (sensu Santos et al., 2012), located east to the Espinhaço Mountain Range (Luiz et al., 2006; Santos et al., 2009).

In the last years, a few avifaunal inventories have been conducted in arboreal caatingas (sensu Santos et al., 2012) on the left bank of the São Francisco River (Kirwan et al., 2001, 2004; Lopes et al., 2010; Dornelas et al., 2012). Nevertheless, there is a gap of detailed ornithological surveys in Cerrado dry forest enclaves on the right bank of this river. Thus, the aim of this paper is to present a bird inventory in a poorly known area located on the right bank of the São Francisco River, named "Curral de Pedras". This area was only briefly sampled by the staff of Museu Nacional, in late November 1995, based on records of $K$. franciscanus reported in the literature (Lima, 1999; Kirwan et al., 2004).

\section{MATERIALS AND METHODS}

\section{Study area}

Curral de Pedras is a hilly site with limestone outcrops at higher elevations, located in the municipality of Jequitaí, central Minas Gerais state, southeastern Brazil, between the coordinates $17^{\circ} 04^{\prime} 36^{\prime \prime} \mathrm{S}$ and $17^{\circ} 06^{\prime} 25^{\prime \prime} \mathrm{S}$, $44^{\circ} 32^{\prime} 48^{\prime \prime} \mathrm{W}$ and $44^{\circ} 35^{\prime} 34^{\prime \prime} \mathrm{W}$ (Fig. 1). This site lies on elevations ranging from $500 \mathrm{~m}$ to $700 \mathrm{~m}$ above sea level. Vegetation is composed mainly by deciduous forest on the slopes, interconnected to a riparian forest along the Riacho Fundo stream. Limestone outcrops occur in the highest points of the study area, with a peculiar flora composed principally by cacti (Cereus jamacaru, Tacinga saxatilis), bromeliads (Encholirium sp.), and sparse trees (Ceiba rubriflora, Ficus sp., Enterolobium contortisiliquum, and Jatropha sp.). Areas subject to human use, occupied by plantations and pastures are also found along the main stream.

\section{Avifaunal survey}

Five expeditions were conducted to the study area, during the following periods: May 07-17, 2016; July 13-17, 2016; September 21-25, 2016; November 09-14, 2016; and January 11-14, 2017, totaling 31 days of field work. Field sampling was regularly conducted from 05:00-15:00 h (daily effort of $10 \mathrm{~h}$ ), totaling $310 \mathrm{~h}$ of sampling effort.

The avifauna survey was based on 10-species lists, also known as MacKinnon lists (see Mackinnon \& Phillips, 1993), a very useful method for rapid assessment surveys and to estimate species richness (Ribon, 2010; MacLeod et al., 2011; Cavarzere et al., 2012). We used the Chao1 estimator for a comparison to the observed richness obtained by field work, following recommendations by Herzog et al. (2002). The data were 1,000-times randomized to produce rarefaction curves of observed and estimated richness, using EstimateS 9.1.0 (Colwell, 2013). We also calculated the index of frequency in MacKinnon lists (IFL) for each species, which was obtained by dividing the number of lists of 10 species in which each species occurred by the total number of lists (Ribon, 2010). Species were treated as frequent (IFL above 10\%), medium frequent (IFL between 5\% and 9.9\%), and infrequent (IFL below 5\%).

Bird species were identified by vocal recognition and by observations with binoculars. Voucher specimens were collected with an air rifle and 10 mist nets, under SISBio permanent permit number 28301-1. Sampling effort of mist nets was $5,200 \mathrm{~m}^{2}$.h (following Straube \& Bianconi, 2002). Specimens were prepared as study skins and have been deposited in the ornithological collection of the Museu de Ciências Naturais da Pontifícia Universidade Católica de Minas Gerais (MCNA), Belo Horizonte, Brazil.

The systematic order and Latin names follow Piacentini et al. (2015), except for Crypturellus zabele, which follows Tomotani \& Silveira (2016), and for Campylopterus calcirupicola, which follows Lopes et al. (2017).

\section{Species accounts and analyzes of geographical variation in some taxa}

We analyzed series of two species of woopeckers (Celeus ochraceus and C. flavescens) and five species of woodcreepers (Sittasomus griseicapillus, Lepidocolaptes wagleri, L. squamatus, Dendrocolaptes platyrostris, and Xiphocolaptes albicollis) that exhibit geographical variation in eastern Brazil (Appendix 1). These analyzes were based on specimens housed in MCNA, in the Coleção Ornitológica do Centro de Coleções Taxonômicas da Universidade Federal de Minas Gerais (DZUFMG), and in the Museu de História Natural e Jardim Botânico da Universidade Federal de Minas Gerais (MHNJBUFMG). Plumage color of these specimens was analyzed in order to detect patterns of geographic variation. For woodcreepers, plumage descriptions were based on Munsell soil color charts (2000). Measurements were taken using callipers and a ruler. Measurements taken (following Baldwin et al., 1931) were: length of total culmen, length of bill from nostril (only for Celeus spp.), length of closed wing, length of tail, and length of tarsus.

\section{RESULTS AND DISCUSSION}

\section{Avifaunal survey}

We recorded 172 bird species at Curral de Pedras (Appendix 2). The rarefaction curve, based on 226 MacKinnon lists, suggests that more species would likely be added in future surveys, with an estimated richness of 196 species (Fig. 2). 


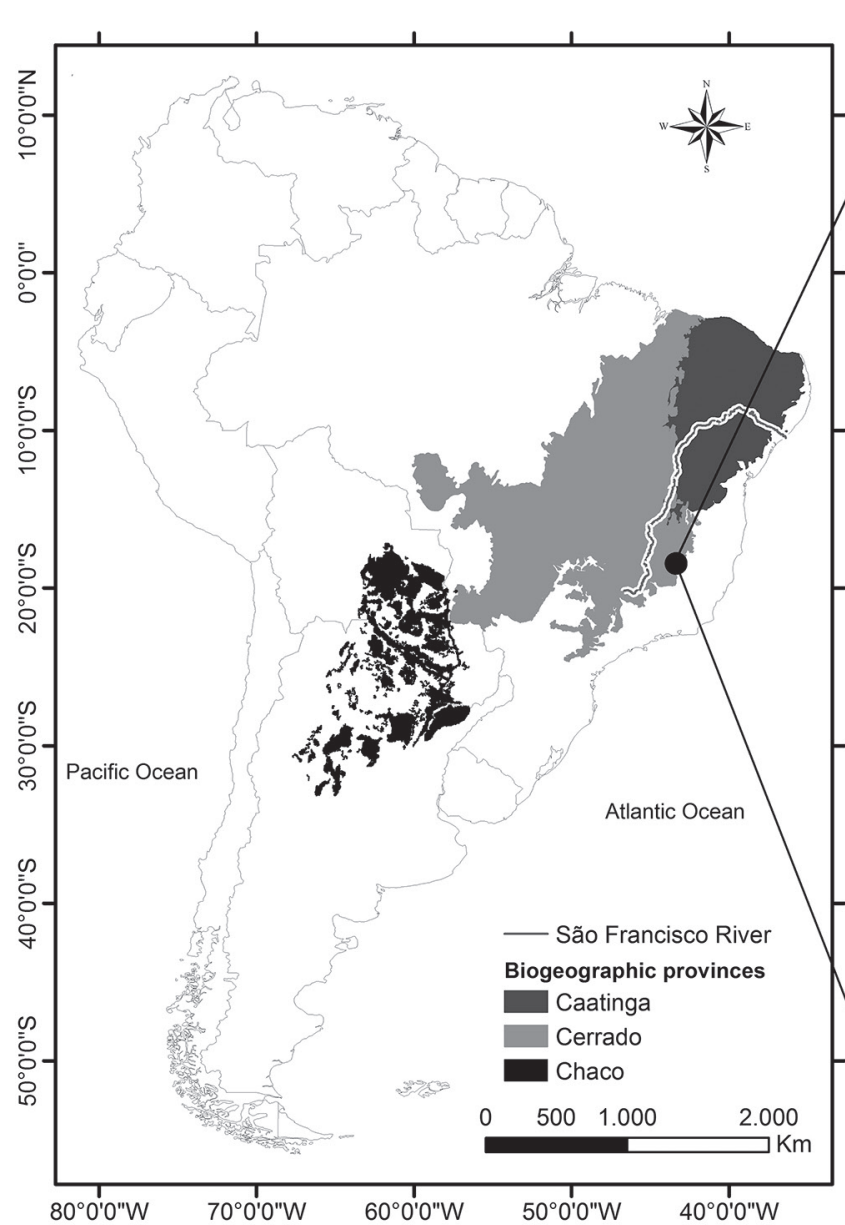

A

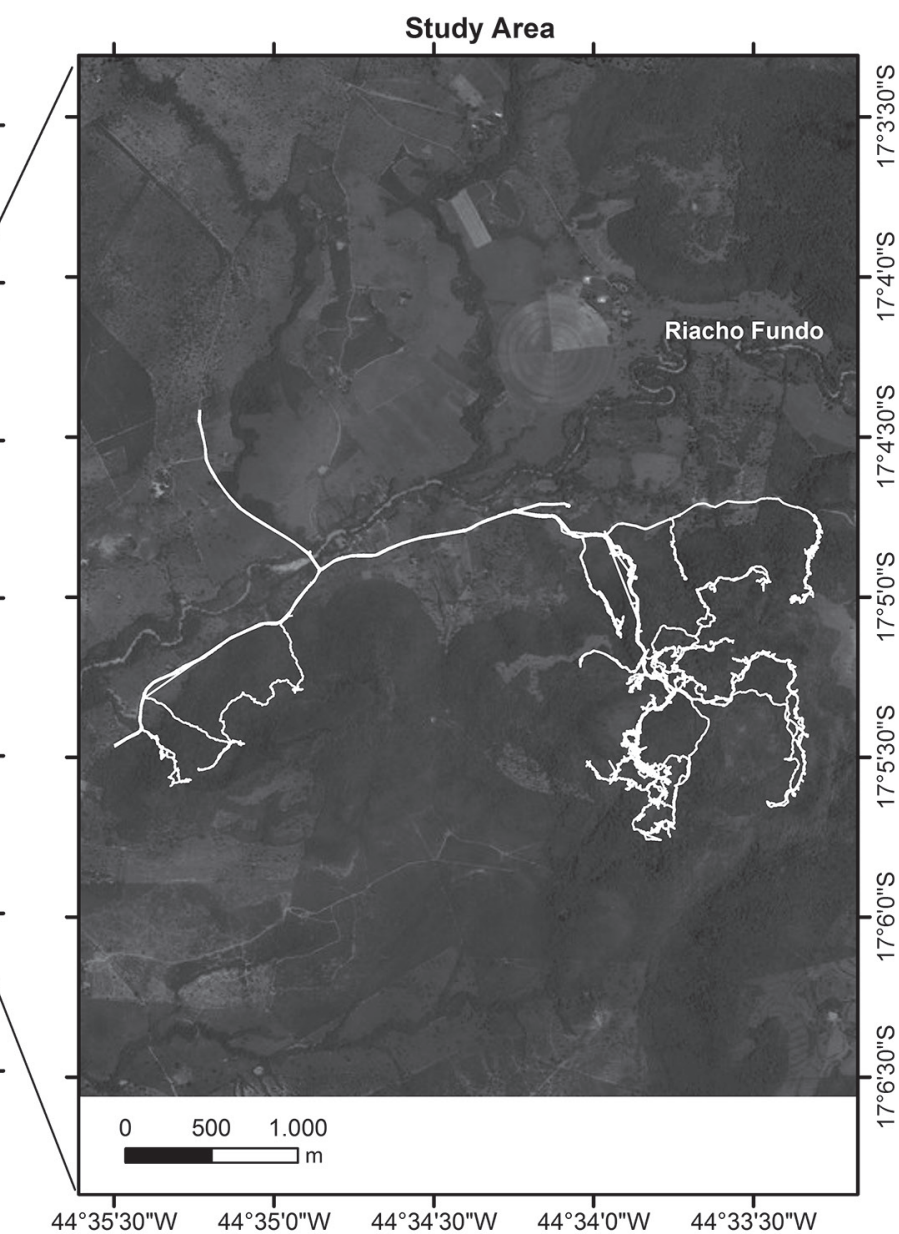

B

Figure 1. Map of the study area in South America (black dot) in the Cerrado biogeographic province and its position in relation to the Caatinga and the Chaco biogeographic provinces (A); detail of the study area at Curral de Pedras with tracks of the sampled trails (white lines) (B).

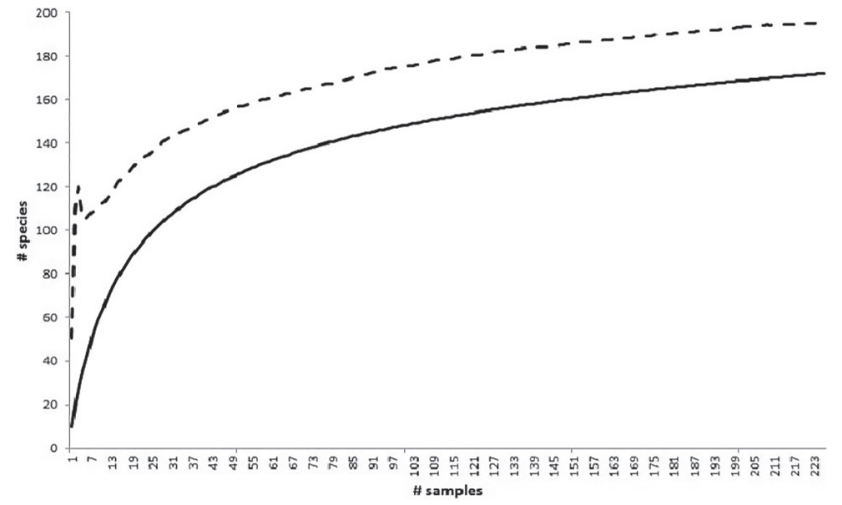

Figure 2. Species rarefaction curve (continuous line) and estimation curve using the Chao1 estimator (dashed line) for the avifauna of Curral de Pedras, Minas Gerais, southeastern Brazil, using 226 MacKinnon lists.

Nine taxa are typical of the Caatinga, whose original ranges are associated with the limits of this biogeographic province (following Pacheco, 2004; Olmos et al., 2005; Vasconcelos et al., 2012): Crypturellus zabele (Yellowlegged Tinamou), Columbina picui strepitans (Picui Ground-Dove), Eupsittula cactorum (Cactus Parakeet), Myrmorchilus strigilatus strigilatus (Stripe-backed
Antbird), Thamnophilus capistratus (Caatinga Antshrike), Schoeniophylax phryganophilus petersi (Chotoy Spinetail), Icterus jamacaii (Campo Troupial), Paroaria dominicana (Red-cowled Cardinal), and Compsothraupis loricata (Scarlet-throated Tanager). On the other hand, Curral de Pedras lacks several other typical birds from the Caatinga province, which have been recorded in adjacent areas of arboreal caatingas (see Kirwan et al., 2001, 2004; Vasconcelos et al., 2006; Vasconcelos \& D'AngeloNeto, 2007; Lopes et al., 2010; Dornelas et al., 2012). This is probably related to this area being a Cerrado dry forest enclave. Examples are: Penelope jacucaca (Whitebrowed Guan), Anopetia gounellei (Broad-tipped Hermit), Picumnus pygmaeus (Spotted Piculet), Herpsilochmus sellowi (Caatinga Antwren), Sakesphorus cristatus (Silverycheeked Antshrike), Hylopezus ochroleucus (Whitebrowed Antpitta), Megaxenopsparnaguae (Great Xenops), Pseudoseisura cristata (Caatinga Cacholote), Synallaxis hellmayri (Red-shouldered Spinetail), Stigmatura budytoides gracilis (Greater Wagtail-Tyrant), Casiornis fuscus (Ash-throated Casiornis), Cantorchilus longirostris bahiae (Long-billed Wren), Arremon franciscanus (São Francisco Sparrow), Agelaioides fringillarius (Pale Baywing), and Sporophila albogularis (White-throated Seedeater). 
Among the typical Caatinga birds recorded at Curral de Pedras, the most frequent were: I. jamacaii (IFL $=20.8 \%$ ), C. picui and M. strigilatus (both with IFL $=13.3 \%)$, and C. loricata (10.2\%). On the other hand, the following species presented low frequency: E. cactorum (3.1\%), T. capistratus (2.2\%), S. phryganophilus (0.9\%), and P. dominicana (0.4\%).

Saltatricula atricollis (Black-throated Saltator) is the only savanna species, which is typical of the Cerrado province (following Silva, 1995, 1997; Silva \& Bates, 2002). This is probably related to the fact that Curral de Pedras is predominantly forested, without typical native open vegetation types. In the study area, the Black-throated Saltator was recorded in low frequency (0.9\%) and only in pastures.

Another species previously considered as a Cerrado endemic (Silva, 1995, 1997; Silva \& Bates, 2002) is Knipolegus franciscanus, but it also occurs in the Caatinga province (Kirwan et al., 2004; Vasconcelos et al., 2006; Lopes et al., 2010; Dornelas et al., 2012), sharing a similar range to Campylopterus calcirupicola (Lopes et al., 2017).

Six taxa are typical of the Atlantic Forest (following Sick, 1997; Brooks et al., 1999; Moreira-Lima, 2013): Aphantochroa cirrochloris (Sombre Hummingbird), Florisuga fusca (Black Jacobin), Trogon surrucura (Surucua Trogon), Sittasomus griseicapillus sylviellus (Olivaceous Woodcreeper), Lepidocolaptes cf. squamatus (Scaled Woodcreeper), and Xiphocolaptes albicollis (Whitethroated Woodcreeper).

The following species are included in red lists of Minas Gerais state (COPAM, 2010) and/or Brazil (ICMBio, 2014): C. zabele, Spizaetus tyrannus (Black Hawk-Eagle), and S. ornatus (Ornate Hawk-Eagle). We failed to find $P$. roquettei, an endangered species at state, national and global levels (COPAM, 2010; ICMBio, 2014; BirdLife International, 2017). Nevertheless, given that it has been recorded in nearby areas (Raposo et al., 2002; Kirwan et al., 2004; Vasconcelos et al., 2006, 2008; Lopes et al., 2008) and that Curral de Pedras habors suitable habitats to this species, such as dry and gallery forests, we suspect that further surveys will find it in the study area.

\section{Species accounts and analyzes of geographic variation in some taxa}

Below, we present comments on the distribution, geographic variation, and natural history of some species.

\section{Campylopterus calcirupicola (Dry-forest Sabrewing)}

This is a recently described species endemic to dry forests of central Brazil (Lopes et al., 2017). Curral de Pedras is located $75 \mathrm{~km}$ southwest from the type locality, in Montes Claros. Despite being a medium frequent species (IFL $=5.8 \%$ ), it was recorded predominantly inside dry forest during the dry season (in May and July), where it was observed visiting flowers of Ruellia brevifolia (Acanthaceae) and Gurania sp. (Cucurbitaceae). During the rainy season (November), it was observed in the vegetation growing over limestone outcrops, visiting flow-
Table 1. Morphometrics and body mass of three female specimens of Campylopterus calcirupicola from Curral de Pedras, Minas Gerais, Brazil.

\begin{tabular}{lccc}
\hline \multicolumn{1}{c}{ Variable } & MCNA 4977 & MCNA 5050 & MCNA 5190 \\
\hline Total length & $137.0 \mathrm{~mm}$ & $135.0 \mathrm{~mm}$ & $138.0 \mathrm{~mm}$ \\
Wing chord & $67.8 \mathrm{~mm}$ & $68.7 \mathrm{~mm}$ & $65.6 \mathrm{~mm}$ \\
Tail & $47.1 \mathrm{~mm}$ & $46.8 \mathrm{~mm}$ & $47.2 \mathrm{~mm}$ \\
Total culmen & $28.4 \mathrm{~mm}$ & $29.0 \mathrm{~mm}$ & $27.9 \mathrm{~mm}$ \\
Longest length of the light tail tip of the & $21.6 \mathrm{~mm}$ & $22.0 \mathrm{~mm}$ & $21.3 \mathrm{~mm}$ \\
first outer rectrix (LTT-1)* & & & \\
Longest length of the light tail tip of the & $20.9 \mathrm{~mm}$ & $23.3 \mathrm{~mm}$ & $20.3 \mathrm{~mm}$ \\
second outer rectrix (LTT-2)* & & & \\
Longest length of the light tail tip of the & $15.0 \mathrm{~mm}$ & $11.2 \mathrm{~mm}$ & $15.1 \mathrm{~mm}$ \\
third outer rectrix (LTT-3)* & & & \\
Longest length of the light tail tip of the & $0.5 \mathrm{~mm}$ & $0.8 \mathrm{~mm}$ & $2.7 \mathrm{~mm}$ \\
fourth outer rectrix (LTT-4)* & & & \\
Rate LTT-2 + LTT-3 / wing chord* & 0.53 & 0.50 & 0.54 \\
Weight & $5.8 \mathrm{~g}$ & $5.5 \mathrm{~g}$ & $5.6 \mathrm{~g}$ \\
\hline
\end{tabular}

* See Lopes et al. (2017) for further details.

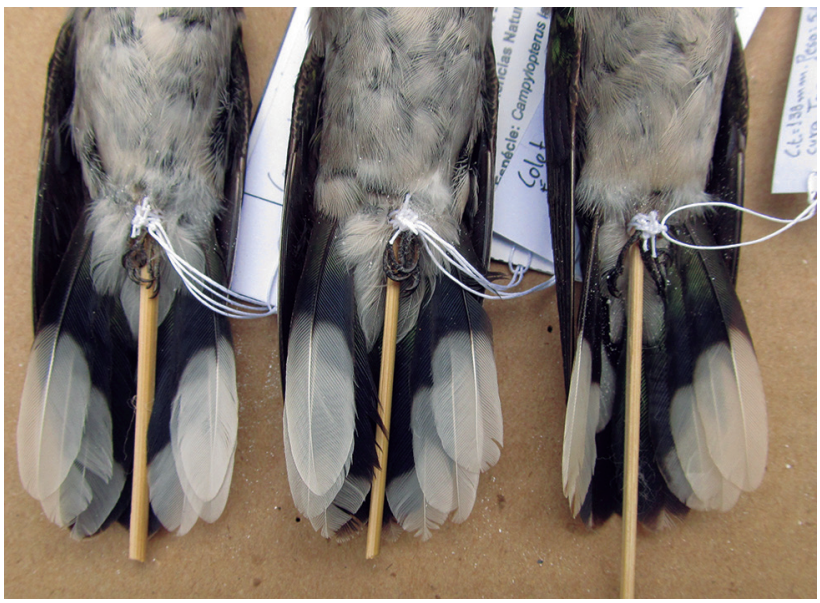

Figure 3. Tails of three female specimens of Campylopterus calcirupicola (from left to right: MCNA 4977, MCNA 5050, MCNA 5190) from Curral de Pedras, Minas Gerais, Brazil.

ers of Tacinga saxatilis (Cactaceae). On September, one individual was observed bathing among wet leaflets of a shrubby legume (Fabaceae).

Three females were collected (MCNA 4977, MCNA 5050, MCNA 5190). Using the identification key provided by Lopes et al. (2017), these specimens match perfectly C. calcirupicola, including rectrices narrow and pointed (in comparison to C. diamantinensis), with bright bronze green basal half (Fig. 3). Measurements and body mass of these specimens are presented on Table 1.

Given the scarcity of records of this species, with only eight known collecting sites (Lopes et al., 2017), the occurrence of $C$. calcirupicola in Curral de Pedras is very important to the knowledge of its range, since it is located at its southernmost limits.

\section{Trogon surrucura (Surucua Trogon)}

This species, sometimes treated as an Atlantic Forest endemic (Brooks et al., 1999), was frequent in our survey 
(IFL $=10.2 \%$ ). All records were obtained in dry and gallery forests. Three specimens were collected: a female (MCNA 4965) and two males (MCNA 5181, MCNA 5182). They represent the nominotypical subspecies, which, in northern Minas Gerais, is the expected taxon occurring west of the Espinhaço Range, in the São Francisco River hydrographic basin (Vasconcelos \& D'Angelo-Neto, 2007). In the eastern slopes of this mountain range, it is replaced by the subspecies $T$. s. aurantius, which lives in semideciduous (Atlantic) forests (Vasconcelos \& D'Angelo-Neto, 2007).

\section{Celeus ochraceus (Ochre-backed Woodpecker)}

Until recently, three subspecies of Celeus flavescens (Blond-crested Woodpecker) were recognized: (1) C. f. flavescens, ranging from southeastern Brazil to eastern Paraguay and northeastern Argentina; (2) C. f. ochraceus, ranging from the lower Amazon region to Maranhão, Ceará, Piauí, and eastern Bahia and Espírito Santo states; and (3) C. f. intercedens, which occurs in intervening areas between the first two subspecies, in western Bahia, Goiás and Minas Gerais states (Short, 1972, 1982; Winkler et al., 1995; Winkler \& Christie, 2002; Dickinson \& Remsen, 2013).

Amongst the most important diagnostic characters of the three subspecies, in C. f. flavescens the mantle, the back, and the upperwing-coverts are black, narrowly barred white; whereas in C. f. ochraceus those parts are tinged of cinnamon-buff with black spots (occasionally absent), varying from heart-shaped to chevron-shaped (Short, 1972, 1982; Winkler et al., 1995; Winkler \& Christie, 2002). Measurements of C. f. flavescens are also larger than those of C. f. ochraceus (Short, 1972; Winkler et al., 1995). Celeus $f$. intercedens has dorsal white bars broader than C. f. flavescens, sometimes presenting the dorsal buffy tinge of C. f. ochraceus (Short, 1972, 1982; Winkler et al., 1995). This subspecies is considered intermediate in size between C. f. flavescens and C.f. ochraceus (Winkler \& Christie, 2002). Despite presenting variable plumage, sometimes considered intermediate in dorsal barring between C. f. flavescens and C. f. ochraceus, and with some of the rust tinge of $C$. $f$. ochraceus, these characters are considered stable in some areas (Short, 1982; Winkler et al., 1995), which led Short (1982) to recognize Celeus f. intercedens as a subspecies. Short (1982) also pointed out that an intergradation zone between $C$. $f$. flavescens and C. f. ochraceus probably occurs in southern Bahia and Espírito Santo states, but without any signal of intermediate and stable phenotypes of $C$. f. intercedens.

Benz \& Robbins (2011), based on molecular data, proposed that $C$. ochraceus deserves full species status instead of being regarded as a subspecies of $C$. flavescens. Nevertheless, these authors pointed out that the taxonomic status of $C$. f. intercedens still needs to be clarifyied, based on populations of $C$. ochraceus that resemble this taxon in suture zones located in Central Brazil.

More recently, Firme (2015) presented a systematic revision of Celeus, in which C. $f$. intercedens was synonymized with $C$. $f$. flavescens, based on the large varia-

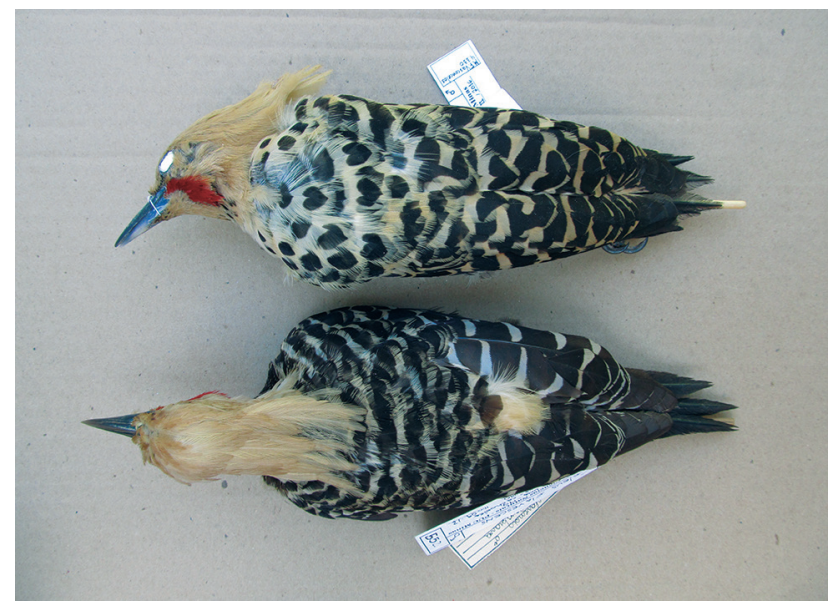

Figure 4. Male specimens of Celeus ochraceus (MCNA 5057) from the study area (above) and Celeus flavescens (MCNA 552) from Fazenda Canabrava, Augusto de Lima, Minas Gerais (below).

tion of diagnostic characters previously assigned to both subspecies. Firme (2015) also considered C. ochraceus as a full species. Thus, in the most recent revision of this complex, only two taxa are considered: C. flavescens (including intercedens) and C. ochraceus.

Celeus ochraceus was infrequent in our sampling (IFL $=4.4 \%)$, occurring exclusively in dry forest habitats. One male was collected (MCNA 5057). It presents cordiform black spots on the back and on the wings (Fig. 4), a diagnostic character of C. ochraceus (Firme, 2015). Measurements of this specimen are also close to the range of the small series $(n \leq 9)$ of $C$. ochraceus analyzed by Short (1972), which are (in mm): wing: 140.0; tail: 83.9; bill (from nostril): 21.0. The only exception is tarsus length $(26.3 \mathrm{~mm})$, which is larger than expected and matches the range of measurements of $C$. flavescens.

It is noteworthy that a male of C. flavescens (MCNA 552) was collected at Fazenda Canabrava (18 $11^{\circ} \mathrm{S}$, $44^{\circ} 03^{\prime} \mathrm{W}$ ), Augusto de Lima municipality, a site located only $130 \mathrm{~km}$ southeast from the study area. Its barred back plumage (Fig. 4) and measurements are within the variation typical of C. flavescens (Short, 1972; Winkler et al., 1995). Measurements are (in mm): wing: 164.0; tail: 94.5; bill (from nostril): 23.8; tarsus length: 27.2 .

This appears to be the southernmost record of the Ochre-backed Woodpecker (Wiki Aves, 2017). Other specimens of $C$. ochraceus collected in its southern range

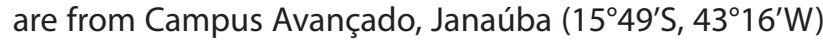
(DZUFMG 3354) and Riacho dos Machados $\left(16^{\circ} 02^{\prime} \mathrm{S}\right.$, $43^{\circ} 08^{\prime} \mathrm{W}$ ) (MCNA 2522, MCNA 2682, MCNA 2763), Minas Gerais. Based on these specimens, there is a possible contact zone of $C$. ochraceus and $C$. flavescens somewhere between the study area and the western slope of the Espinhaço Range.

\section{Sittasomus griseicapillus (Olivaceous Woodcreeper)}

This species was frequent in the present sampling (IFL $=12.8 \%$ ). In northern Minas Gerais, two subspecies of the Olivaceous Woodcreeper have been recorded: 


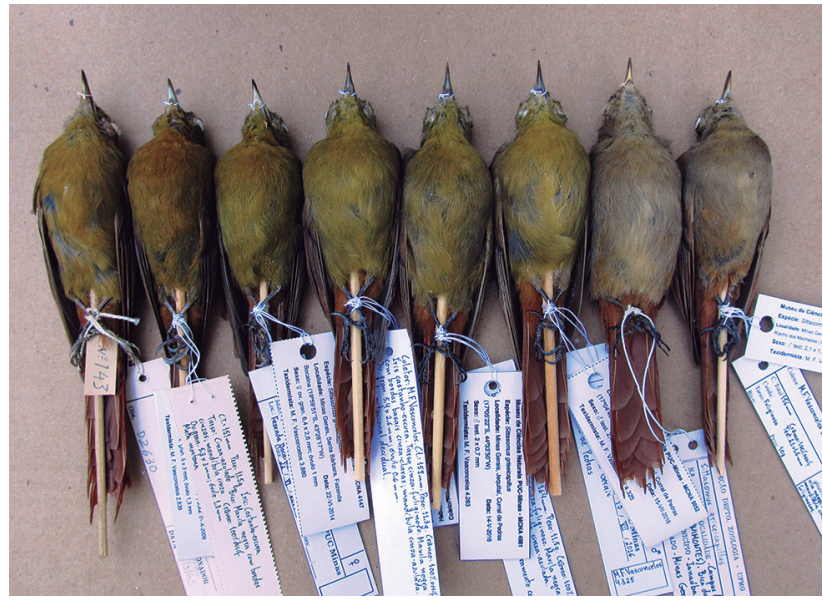

Figure 5. From left to right: specimens of Sittasomus griseicapillus sylvielIus from Santa Teresa, Espírito Santo (DZUFMG 630), Mariana, Minas Gerais (MCNA 1406), Santa Bárbara, Minas Gerais (MCNA 4147), Curral de Pedras, Minas Gerais (MCNA 4970, MCNA 4981, MCNA 5052); and specimens of Sittasomus griseicapillus reiseri from Janaúba, Minas Gerais (DZUFMG 3428), and Riacho dos Machados, Minas Gerais (MCNA 2523).

S. g. sylviellus and S. g. reiseri (Vasconcelos \& D'AngeloNeto, 2007). In this region, S. g. sylviellus is associated to semideciduous (Atlantic) forests from eastern Espinhaço Range, while S. g. reiseri occurs in the arboreal caatingas and deciduous forests west of this mountain range (Vasconcelos \& D'Angelo-Neto, 2007). Thus, it was unexpected that the three specimens obtained in the study area (west of the Espinhaço Range) exhibit the typical plumage pattern of the Atlantic S. g. sylviellus (Fig. 5). Nevertheless, specimens from Curral de Pedras present underparts olive yellow $(2.5 \mathrm{Y} 6 / 6)$, slightly paler than specimens of this taxon collected in moister forests eastward, which present underparts light olive brown (2.5Y 5/6). This corroborates Gloger's ecogeographic rule, in which specimens from drier environments would exhibit lighter plumages than those from more humid regions (Gloger, 1833). Similar results that corroborate Gloger's ecogeographic rule were also observed in detailed studies of geographic variation of two other woodcreepers: Lepidocolaptes angustirostris (Narrow-billed Woodcreeper) (Bolívar-Leguizamón \& Silveira, 2015) and Dendrocolaptes platyrostris (Planalto Woodcreeper) (Cabanne et al., 2011).

Silva (1989) reported hybrid zones of S. g. sylviellus and S. g. reiseri in the Araguaia - São Francisco interfluve. Nevertheless, in northern Minas Gerais, we never found any signal of intergradation between both subspecies based on specimens collected over a long transect crossing the Espinhaço Range (Vasconcelos \& D'Angelo-Neto, 2007). A comparison between specimens of S. g. reiseri from southern Caatinga province (northern Minas Gerais) and a topotype from northern Caatinga (southern Piauí - MCNA 5386) also suggests that this taxon tends to be darker in its southernmost range. The topotype of S. g. reiseri presents breast light olive brown (2.5Y 5/4), belly yellowish brown (10YR 5/6), and head olive brown (2.5Y 4/4). Southern specimens of S. g. reiseri have breast olive brown (2.5Y 4/4), belly light olive brown (2.5Y 5/6), and head olive brown (2.5Y 4/3). Thus, further analyses and collecting of specimens in the Caatinga province are needed to test if this pattern is related to Gloger's ecogeographic rule.

\section{Lepidocolaptes cf. squamatus (Scaled Woodcreeper)}

This species was frequent during our survey (IFL $=19.5 \%)$, occurring mainly in dry forest and its borders. We collected two specimens (MCNA 4978, MCNA 5237). Both exhibit plumage of crown as assigned for L. squamatus (following Silva \& Straube, 1996). Nevertheless, their underparts are more similar to that of L. wagleri, showing inconspicuous dark borders on the streaks of breast and belly (Fig. 6). Other specimens also present intermediate plumage between $L$. wagleri and $L$. squamatus (Silva \& Straube, 1996; Vasconcelos et al., 2012; see also
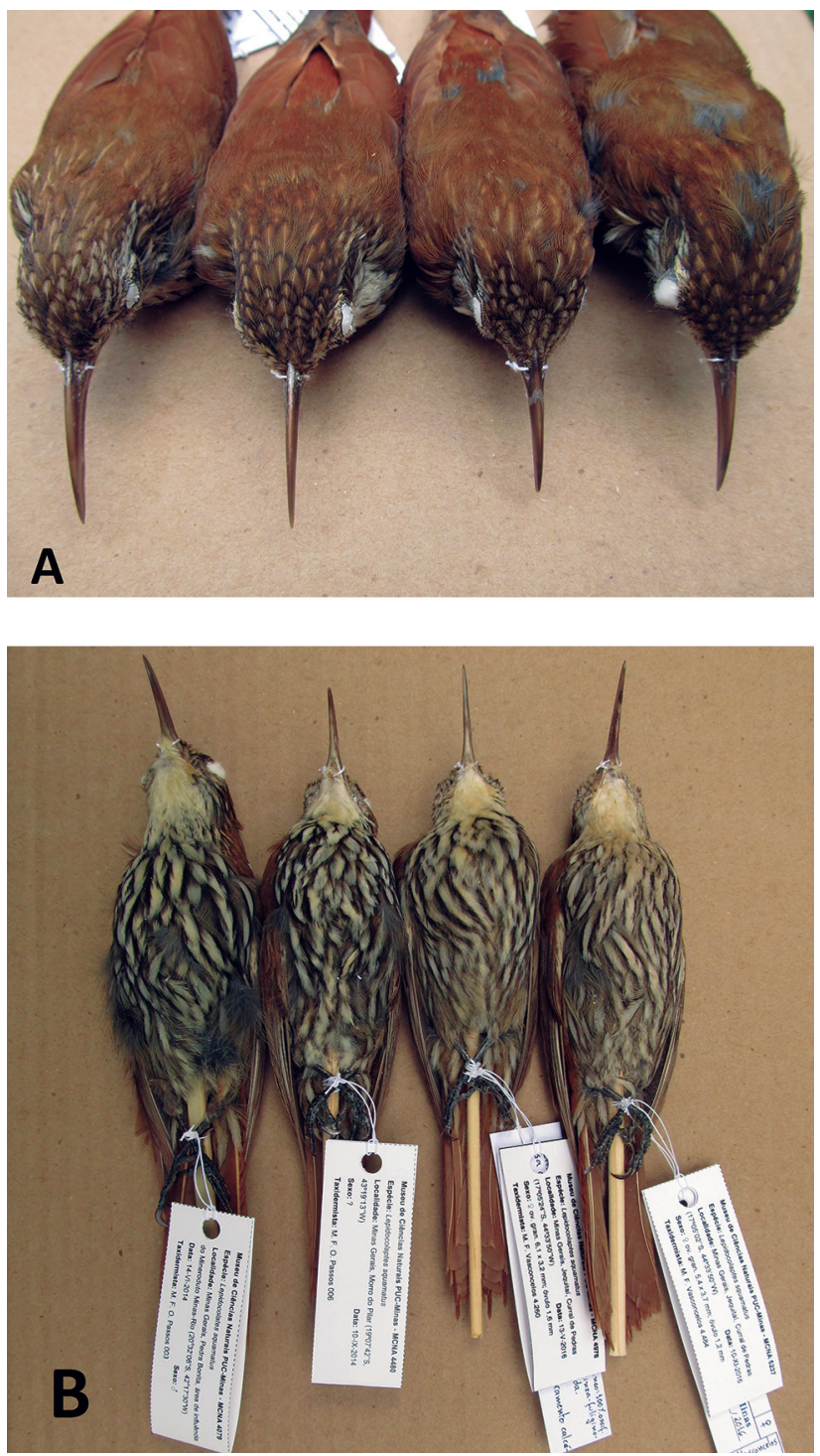

Figure 6. From left to right: specimens of Lepidocolaptes squamatus from Pedra Bonita, Minas Gerais (MCNA 4079), Morro do Pilar, Minas Gerais (MCNA 4480); and specimens of Lepidocolaptes (f. squamatus from Curral de Pedras, Minas Gerais (MCNA 4978, MCNA 5237) in frontal (A) and ventral (B) views. 
Table 2. Plumage characters of four specimens of Dendrocolaptes platyrostris collected in Curral de Pedras, Minas Gerais, Brazil.

\begin{tabular}{|c|c|c|c|c|}
\hline Character & MCNA 5051 & MCNA 5189 & MCNA 5235 & MCNA 5236 \\
\hline Head & $\begin{array}{l}\text { External vane very dark grayish brown } \\
\text { (10YR } 3 / 2) \text { and internal vane very pale } \\
\text { brown (10YR } 8 / 2 \text { ) [state } 2^{*} \text { ] }\end{array}$ & $\begin{array}{l}\text { External vane black ( } 2.5 Y 2.5 / 1) \text { and internal } \\
\text { vane very pale brown (10YR } 8 / 2) \text { [no } \\
\text { correspondent state* }\end{array}$ & $\begin{array}{l}\text { External vane very dark gray (10YR } 3 / 1) \text { and } \\
\text { internal vane very pale brown (10YR } 8 / 2) \text { [no } \\
\text { correspondent state }{ }^{*} \text {. }\end{array}$ & $\begin{array}{l}\text { External vane very dark grayish brown } \\
(10 Y R 3 / 2) \text { and internal vane very pale } \\
\text { brown }(10 Y R 8 / 2) \text { [state } 2^{*} \text { ] }\end{array}$ \\
\hline Tail & Dark reddish brown (5YR 3/4) [state 3*] & $\begin{array}{l}\text { Dark reddish brown (5YR } 3 / 3 \text { ) [no } \\
\text { correspondent state* }\end{array}$ & Dark reddish brown (5YR 3/2) [state $6^{*}$ ] & Dark reddish brown (5YR 3/2) [state $6^{*}$ ] \\
\hline Uppertail & $\begin{array}{l}\text { Unbarred with background dark brown } \\
\text { ( } 7.5 Y R 3 / 4 \text { ) and a black patch at the } \\
\text { subterminal portion of feathears [state } 6^{*} \text { ] }\end{array}$ & $\begin{array}{l}\text { Unbarred with background dark brown } \\
\text { (7.5YR } 3 / 4 \text { ) without black patch at the } \\
\text { subterminal portion of feathears [no } \\
\text { correspondent state*] }\end{array}$ & $\begin{array}{l}\text { Unbarred with background dark brown } \\
\text { (7.5YR } 3 / 4) \text { without black patch at the } \\
\text { subterminal portion of feathears [no } \\
\text { correspondent state*] }\end{array}$ & $\begin{array}{l}\text { Unbarred with background dark brown } \\
(7.5 Y R 3 / 4) \text { without black patch at the } \\
\text { subterminal portion of feathears [no } \\
\text { correspondent state*] }\end{array}$ \\
\hline Back & $\begin{array}{l}\text { Finely streaked, external vane brown } \\
\text { (10YR 4/3) and internal vane very pale } \\
\text { brown (10YR } 8 / 2 \text { ) without black mark } \\
\text { at distal portion of internal vane [no } \\
\text { correspondent state* }\end{array}$ & $\begin{array}{l}\text { Finely streaked, external vane dark olive } \\
\text { brown (10YR 3/4) and internal vane very } \\
\text { pale brown (10YR 8/2) without black } \\
\text { mark at distal portion of internal vane [no } \\
\text { correspondent state* }\end{array}$ & $\begin{array}{l}\text { Finely streaked, external vane dark olive } \\
\text { brown (10YR } 3 / 4) \text { and internal vane very } \\
\text { pale brown (10YR } 8 / 2 \text { ) without black } \\
\text { mark at distal portion of internal vane [no } \\
\text { correspondent state* }\end{array}$ & $\begin{array}{l}\text { Finely streaked, external vane dark olive } \\
\text { brown (10YR 3/4) and internal vane very } \\
\text { pale brown (10YR 8/2) without black } \\
\text { mark at distal portion of internal vane [no } \\
\text { correspondent state*] }\end{array}$ \\
\hline Vent & $\begin{array}{l}\text { Background light yellowish brown }(2.5 Y \text { 6/4) } \\
\text { and bars very dark grayish brown }(2.5 Y 3 / 2) \\
\text { [state } 2^{*} \text { ] }\end{array}$ & $\begin{array}{l}\text { Background light yellowish brown }(2.5 \mathrm{Y} 6 / 4) \\
\text { and bars very dark grayish brown }(2.5 \mathrm{Y} 3 / 2) \\
\text { [state } 2^{*} \text { ] }\end{array}$ & $\begin{array}{l}\text { Background light yellowish brown (2.5Y 6/4) } \\
\text { and bars very dark grayish brown }(2.5 \mathrm{Y} 3 / 2) \\
\text { [state } 2^{*} \text { ] }\end{array}$ & $\begin{array}{l}\text { Background light yellowish brown (2.5Y } 6 / 4) \\
\text { and bars very dark grayish brown }(2.5 \mathrm{Y} 3 / 2) \\
\text { [state } 2^{*} \text { ] }\end{array}$ \\
\hline
\end{tabular}

*Following Cabanne et al. (2011).

Appendix 1). Thus, it is worthy that a detailed revision coupling molecular and morphological data is conducted within this complex in order to understand a possible intergradation zone between the two taxa.

\section{Dendrocolaptes platyrostris (Planalto Woodcreeper)}

Dendrocolaptes platyrostris was medium frequent in our sampling (IFL $=6.2 \%$ ), being recorded almost exclusively in dry forest habitat $(92.9 \%, n=13)$, with a single record $(7.1 \%)$ in the adjacent gallery forest.

Currently, two subspecies of $D$. platyrostris are recognized: D. p. platyrostris and D. p. intermedius (Marantz, 1997; Marantz et al., 2003). A comprehensive revision of plumage variation of this species was recently presented by Cabanne et al. (2011), who found two areas of plumage stability: one in the Cerrado of central Brazil (population I) and another in southern Atlantic Forest (population II). They considered that population I represents $D$. p. intermedius and population II is represented by D. p. platyrostris, despite their type localities are out of those areas of plumage stability.

We collected four specimens of $D$. platyrostris in the study area (MCNA 5051, MCNA 5189, MCNA 5235, MCNA 5236). They are intermediate between both stable populations found by Cabanne et al. (2011), which also suggests geographic variation following Gloger's ecogeographic rule. This was expected because Curral de Pedras is located between the range of the two areas of plumage stability. Also, the study area represents a collection gap for D. platyrostris. Thus, a detailed description of the plumage of the four specimens is presented on Table 2, following Cabanne et al. (2011). Despite presenting small interindividual variation, the specimens' overall plumage pattern is darker and more similar to population II (southern Atlantic Forest) than to population I (central Brazil) (Table 2). Some character states from our series do not correspond to any of those described by Cabanne et al. (2011) (Table 2).

\section{Xiphocolaptes albicollis (White-throated Woodcreeper)}

This was a medium frequent species during our survey (IFL $=6.2 \%)$, recorded exclusively in dry forest. We collected a pair in the study area (MCNA 5203, MCNA 5204). The plumage features of the specimens collected in the study area matches the description of the subspecies $X . a$. bahiae. So far, $X . a$. bahiae has been reported to occur only in the state of Bahia (Cory, 1919; Marantz et al., 2003). In comparison with specimens of the nominotypical subspecies from Três Rios (Rio de Janeiro) and Bertioga, São Paulo, they are generally paler (Fig. 7), with crown and nape very dark brown (10YR 2/2) to very dark grayish brown (10YR 3/2) with streaks varying between very pale brown (10YR 7/3.5) and light pale brown (10YR 6/3). In comparison to nominotypical specimens, crown and nape contrast less with brown (10YR 4/2.5) back. Cheeks are unstreaked, varying between pale yellow (2.5Y 8/2) and light gray (2.5Y 7/2). These cheeks form a continuous moustachial stripe to a loral spot of the same color, a pattern that resembles $X$. falcirostris. Breast and sides varies between brown (10YR 5/3) and light olive brown (2.5Y 5/3), with streaks light yellowish brown (2.5Y 6.5/3), without dark spots on their borders. Belly is less barred in comparison to specimens of nominotypical race. Another character that approaches these specimens to $X$. falcirostris is their more pronounced decurved bills (Fig. 7).

Studied specimens from humid (Atlantic) forests of the nominotypical subspecies are generally darker than specimens from Curral de Pedras (Fig. 7). Head and nape are black (10YR 2/1), with streaks varying between very pale brown (10YR 7/4) and light yellowish brown (10YR 6/4), contrasting deeply with back that varies between very dark grayish brown (10YR 3/2) and dark yellowish brown (10YR 3/4). Cheeks are usually white (2.5Y 8/1) striped black (10YR 2/1) or very dark brown (10YR 2/2). Breast varies between dark grayish brown (10YR 4/2), brown (10YR 4/3), and dark yellow- 
ish brown (10YR 4/4), with streaks pale yellow (2.5Y $7 / 3$ and $2.5 \mathrm{Y} 7 / 4$ ) bordered by spots very dark grayish brown (10YR 3/2). Belly presents a denser barring pattern than those specimens of dry forests.

It is noteworthy that in specimens collected in semideciduous forests, between areas of humid and dry forests, the plumage pattern appears to be intermediate between $X$. a. albicollis and X.a. bahiae. They present dark head and striped cheeks similar to specimens of the nominotypical subspecies. Nevertheless, the breast streaks are never bordered by dark spots and belly barring is less pronounced, similar to $X$. $a$. bahiae. The background color of breast and upperparts present a wide variation among specimens, with some resembling those of $X$. a. albicollis and others with a pattern closer to that of X. a. bahiae (Fig. 7).

We checked photographs of the type of $X$. a. bahiae, housed in the Field Museum of Natural History (FMNH 65976), and its overall plumage pattern is similar to spec-
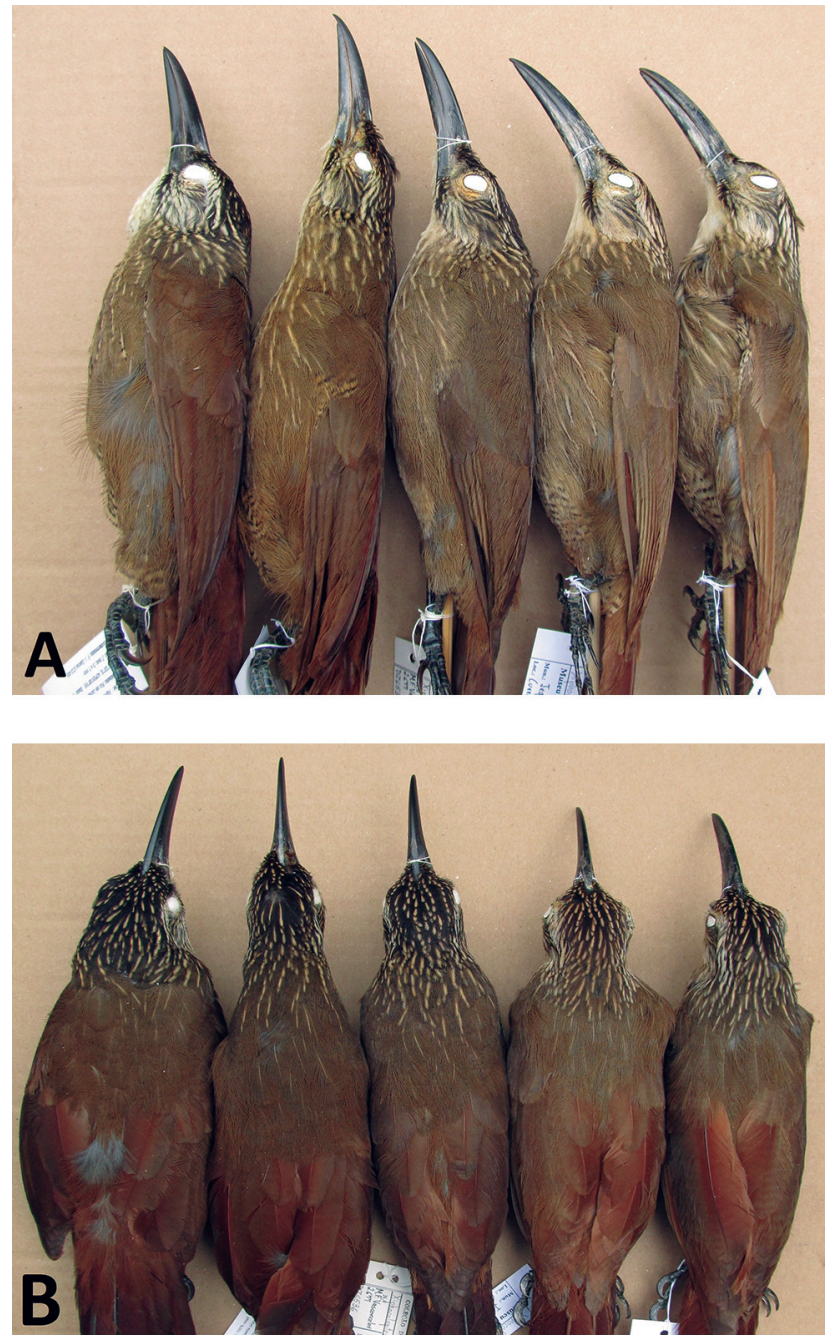

Figure 7. From left to right: specimens of Xiphocolaptes albicollis albicollis from Três Rios, Rio de Janeiro (MCNA 2061); intermediate specimens between X. a. bahiae and X. a. albicollis from Conceição do Mato Dentro, Minas Gerais (MCNA 2903) and Mariana, Minas Gerais (DZUFMG 6536); and specimens of X. a. bahiae from Curral de Pedras, Minas Gerais (MCNA 5203, MCNA 5204) in lateral $(\mathrm{A})$ and dorsal $(\mathrm{B})$ views. imens collected at Curral de Pedras, except for its more streaked back and its rump that appears more rufescent. We also analyzed a photograph of a topotypical specimen, which presents a similar plumage pattern of both specimens collected in the study area (Silva, 2015). Pinto \& Camargo (1961), based on the analysis of the two specimens of $X$. a. villanovae used in the original description of this subspecies, suggested a relationship of this taxon to $X$. a. bahiae. We checked photographs of the type of $X$. a. villanovae, housed in the Museu de Zoologia da Universidade de São Paulo (MZUSP 7593) and it differs from $X$. a. bahiae by presenting a very strong streaked pattern on the back and a densely barred belly. Nevertheless, since both type localities of $X$. a. villanovae and $X$. a. bahiae are located east to the Espinhaço Range in Bahia state, it is possible that $X$. $a$. villanovae is just an extreme of the cline occurring in its northern range.

These results also suggest a geographical variation in X. albicollis following the Gloger's ecogeographic rule, with darker specimens from the humid coastal forests and paler specimens from dry forests. Intermediate specimens do occur between these regions in semideciduous forests. Also, the less contrasting head and nape with back, the conspicuous moustachial stripe, the less barred abdomen, and the more decurved bill of specimens from Curral de Pedras approach them to $X$. falcirostris, known to occur only in the opposite (left) bank of the São Francisco River (Silva \& Oren, 1997). Cory \& Hellmayr (1925) were the first to note that "by the lighter, less blackish pileum, less distinctly streaked auriculars, and absence of black barring underneath $X$. a. bahiae seems to form the transition to $X$. falcirostris, of northeastern Brazil". This suggests a possible gene flow between both species. Thus, we strongly suggest that further detailed taxonomic revisions and phylogeographic studies must be conducted to access the possible clinal variation in $X$. albicollis and to test possible hybridization of this species with $X$. falcirostris, which also shows a not well resolved pattern of geographic variation (Silva \& Oren, 1997). In future studies it would be extremely important to collect specimens from intermediate localities between the known range of these taxa, including the subspecies $X$. a. villanovae, sometimes treated as a subspecies of $X$. falcirostris (Cory \& Hellmayr, 1925 - but see Meyer de Schauensee, 1966; Pinto, 1938), and X. f. franciscanus, previously considered closer to X. albicollis (Pinto, 1978).

\section{Knipolegus franciscanus (Caatinga Black-Tyrant)}

The Caatinga Black-Tyrant was a frequent species in the study area (IFL = 15.0\%). In the same area, Marcos A. Raposo observed c. 50 individuals of this species in a single hour of field sampling in November 1995 (Kirwan et al., 2004), despite we never found it in such abundance (see below). The majority of records of habitat use were obtained in dry forests or their edges $(77.1 \%, n=27)$, despite we also observed it in the vegetation growing on limestone outcrop $(20 \%, n=7)$ and in gallery forest $(2.9 \%, n=1)$. Among all individuals observed during our sampling effort of 31 days $(n=43)$, the majority were 
Table 3. Testicle measurements (in $\mathrm{mm}$ ) of seven male specimens of Knipolegus franciscanus collected at Curral de Pedras between May 2016 and January 2017.

\begin{tabular}{ccc}
\hline Specimen number & Testicle measurements & Month \\
\hline MCNA 5227 & $3.5 \times 1.4$ & January \\
MCNA 4966 & $2.6 \times 1.4$ & May \\
MCNA 5055 & $2.5 \times 1.6$ & July \\
MCNA 5049 & $2.1 \times 1.2$ & July \\
MCNA 5180 & $5.6 \times 3.2$ & September \\
MCNA 5230 & $6.6 \times 3.6$ & September \\
MCNA 5268 & $7.4 \times 4.6$ & November \\
\hline
\end{tabular}

males $(90.7 \%)$, while only $9.3 \%$ were represented by females. We do not know if females are actually less abundant than males or if they present a more secretive behavior, which, together with their more cryptic plumage pattern, make them less detectable than males. In a proportional rate, we obtained eight specimens represented by seven males (MCNA 4966, MCNA 5049, MCNA 5055, MCNA 5180, MCNA 5227, MCNA 5230, MCNA 5268) and a single female (MCNA 5191).

Nothing is known about the species' breeding biology, but based on measurements of testicle size of the seven collected males, breeding appears to occur during the end of dry season and the beginning of the rainy season, between September and November (Table 3).

\section{CONCLUSION}

The data presented here shows that the avifauna of a Cerrado dry forest enclave in central Minas Gerais present a few taxa typical of the Caatinga, despite located only c. $100 \mathrm{~km}$ south of this biogeographic province. This suggests extinction of Caatinga species as other dry forest enclaves are far from this SDTF nucleous. Also, the size of dry forest enclaves, coupled with their distance in relation to the Caatinga province, appears to be an important factor shaping the occurrence of Caatinga birds. For example, in the Paranã River Valley, the largest Cerrado dry forest enclave (Werneck, 2011), with a considerable area of c. $13,000 \mathrm{~km}^{2}$ (Bianchi \& Haig, 2013), but c. $300 \mathrm{~km}$ west of the Caatinga, only the following taxa have been reported: Columbina picui strepitans, Icterus jamacaii, and Compsothraupis loricata (Blamires et al., 2002; Pacheco \& Olmos, 2006; Martins, 2007). Nevertheless, other factors should be responsible for this pattern, since several phytophisiognomies occurring in the Caatinga do not occur in Central Brazilian dry forests (AndradeLima, 1981; Rizzini, 1997), probably excluding some taxa typical to this biogeographic province. Thus, we suggest future studies aiming to understand these patterns of occurrence of typical Caatinga birds in the Cerrado dry forest enclaves.

Finally, based on the specimens collected during this study, we reinforce the need of further research in taxonomy, geographic variation, and phylogeography of the two species complex of woodcreepers that were sug- gested to occur on different banks of the São Francisco River: Lepidocolaptes squamatus (right bank) / L. wagleri (left bank) and Xiphocolaptes albicollis (right bank) / X. falcirostris (left bank). In comparison to Amazonian rivers, the São Francisco River seems not to work as an effective geographic barrier to prevent gene flow between woodcreepers species (Marantz et al., 2003). Future detailed phylogeographic studies and taxonomic revisions should focus on the possible intergradation between L. squamatus / L. wagleri and X. albicollis / X. falcirostris in the dry forests occurring across this river.

\section{ACKNOWLEDGEMENTS}

We are grateful to Instituto Prístino staff, especially Luciana Hiromi Yoshino Kamino, Flávio Fonseca do Carmo, Jeanine Barailon, and Tarcísio Tolentino for logistic and financial support to our fieldwork. Rubens Custódio da Mota, Rogério Tobias Junior, and Wanderlei Oliveira da Silva provided valuable help in the field. The last and his family (D. Santa and Thiago) are the landowners of the study area and allowed our collecting activities there. Eric Pereira (Geoprocessamento - Instituto Prístino) kindly prepared Fig. 1. Dr. Luís Fábio Silveira sent photographs of the type of Xiphocolaptes albicollis villanovae and revised the manuscript. We are grateful to Dr. Marcos A. Raposo, coordinator of the project "Catálogo de Tipos de Espécies de Aves do Brasil/CNPq/Museu Nacional", who permitted checking photographs of the types of Celeus flavescens intercedens and Xiphocolaptes albicollis bahiae. Dr. Daniel Honorato Firme commented on the diagnosis of C. ochraceus. Dr. Marco Aurélio Crozariol and Lia Nahomi Kajiki helped to find bibliographic material. We thank Dr. Marcos Maldonado Coelho for a critical review of the manuscript and for lending the Munsell soil color charts. The first author thanks to the Ministério Público do Estado de Minas Gerais - Coordenadoria Regional das Promotorias de Justiça de Meio Ambiente das Bacias dos Rios Verde Grande e Pardo, for the institutional support to the project IP.064.2016.

\section{REFERENCES}

Andrade-Lima, D. 1981. The caatinga dominium. Revista Brasileira de Botânica, 4: 149-153.

Arruda, D.M.; Ferreira-Júnior, W.G.; Duque-Brasil, R. \& Schaefer, C.E.R. 2013. Phytogeographical patterns of dry forests sensu stricto in northern Minas Gerais State, Brazil. Anais da Academia Brasileira de Ciências, 85: 623-634.

Baldwin, S.P.; Oberholser, H.C. \& Worley, L.G. 1931. Measurements of birds. Scientific Publications of the Cleveland Museum of Natural History, 5: $1-164$.

Benz, B.W. \& Robbins, M.B. 2011. Molecular phylogenetics, vocalizations, and species limits in Celeus woodpeckers (Aves: Picidae). Molecular Phylogenetics and Evolution, 61: 29-44.

Bianchi, C.A. \& Haig, S.M. 2013. Deforestation trends of tropical dry forests in Central Brazil. Biotropica, 45: 395-400.

BirdLife International. 2017. Species factsheet: Phylloscartes roquettei. Available at: www.birdlife.org. Access in: 30/04/2017. 
Blamires, D.; Lemes, M.J.; Carvalho, C.C.; Souza, C.R.P. \& Mendonça, C.V. 2002. 0 corrência de Columbina picui strepitans Spix, 1825 na região de Mambaí, nordeste do Estado de Goiás, Brasil (Columbiformes: Columbidae). Ararajuba, 10: 99-100.

Bolívar-Leguizamón, S. \& Silveira, L.F. 2015. Morphological variation and taxonomy of Lepidocolaptes angustirostris (Vieillot, 1818) (Passeriformes: Dendrocolaptidae). Papéis Avulsos de Zoologia, 55: 281-316.

Brooks, T.; Tobias, J. \& Balmford, A. 1999. Deforestation and bird extinctions in the Atlantic forest. Animal Conservation, 2: 211-222.

Cabanne, G.S.; D'Horta, F.M.; Meyer, D.; Silva, J.M.C. \& Miyaki, C.Y. 2011. Evolution of Dendrocolaptes platyrostris (Aves: Furnariidae) between the South American open vegetation corridor and the Atlantic Forest. Biological Journal of the Linnean Society, 103: 801-820.

Cavarzere, V.; Costa, T.V.V. \& Silveira, L.F. 2012. On the use of 10-minute point counts and 10-species lists for surveying birds in lowland Atlantic Forests in southeastern Brazil. Papéis Avulsos de Zoologia, 52: 333-340.

Colwell, R.K. 2013. Estimates: Statistical estimation of species richness and shared species from samples. Version 9. Available at: http://viceroy.eeb. uconn.edu/estimates. Access in: 28/04/2014.

COPAM - Conselho Estadual de Política Ambiental. 2010. Deliberação Normativa COPAM № 147, de 30 de abril de 2010. Aprova a lista de espécies ameaçadas de extinção da fauna do estado de Minas Gerais. Publicação - Diário do Executivo - "Minas Gerais" - 04/05/2010. Available at: $w$ ww.siam.mg.gov.br/sla/download.pdf?idNorma=13192. Access in: 01/03/2014.

Cory, C.B. 1919. Descriptions of three new South American birds. The Auk, 36 : 540-541.

Cory, C.B. \& Hellmayr, C.E. 1925. Catalogue of birds of the Americas. Part IV: Furnariidae - Dendrocolaptidae. Field Museum of Natural History, Zoological Series, 13: 1-390.

Dickinson, E.C. \& Remsen Jr., J.V. 2013. The Howard and Moore complete checklist of the birds of the World. Volume 1: Non-passerines. 4.ed. Eastbourne, Aves Press. 461p.

Dornelas, A.A.F.; Paula, D.C.; Espírito-Santo, M.M.; Sánchez-Azofeifa, G.A. \& Leite, L.0. 2012. Avifauna do Parque Estadual da Mata Seca, norte de Minas Gerais. Revista Brasileira de Ornitologia, 20: 378-391.

DryFlor; Banda-R., K.; Delgado-Salinas, A.; G. Dexter, K.G.; Linares-Palomino, R.; Oliveira-Filho, A.; Prado, D.; Pullan, M.; Quintana, C.; Riina, R.; Rodríguez M., G.M.; Weintritt, J.; Acevedo-Rodríguez, P.; Adarve, J.; Álvarez, E.; Aranguren B., A.; Arteaga, J.C.; Aymard, G.; Castaño, A.; Ceballos-Mago, N.; Cogollo, Á.; Cuadros, H.; Delgado, F.; Devia, W.; Dueñas, H.; Fajardo, L.; Fernández, Á.; Fernández, M.Á.; Franklin, J.; Freid, E.H.; Galetti, L.A.; Gonto, R.; González-M., R.; Graveson, R.; Helmer, E.H.; Idárraga, Á.; López, R.; Marcano-Veja, H.; Martínez, O.G.; Maturo, H.M.; McDonald, M.; McLaren, K.; Melo, 0.; Mijares, F.; Mogni, V.; Molina, D.; Moreno, N. del P.; Nassar, J.M.; Neves, D.M.; Oakley, L.J.; Oatham, M.; Olvera-Luna, A.R.; Pezzini, F.F.; Dominguez, O.J.R.; Ríos, M.E.; Rivera, 0.; Rodríguez, N; Rojas, A.; Särkinen, T.; Sánchez, R.; Smith, M.; Vargas, C.; Villanueva, B. \& Pennington, R.T. 2016. Plant diversity patterns in neotropical dry forests and their conservation implications. Science, 353: 1383-1387.

Espírito-Santo, M.M.; Sevilha, A.C.; Anaya, F.C.; Barbosa, R.; Fernandes, G.W.; Sanchez-Azofeifa, G.A.; Scariot, A.; Noronha, S.E. \& Sampaio, C.A. 2009. Sustainability of tropical dry forests: two case studies in southeastern and central Brazil. Forest Ecology and Management, 258: 922-930.

Firme, D.H. 2015. Revisão sistemática de Celeus Boie, 1831 (Aves: Piciformes: Picidae). (Ph.D. Dissertation). Universidade de São Paulo, São Paulo, Brazil.

Gloger, C.L. 1833. Das Abandern der Vögel durch Einfluss des Klimas. Breslau, A. Schulz.
Herzog, S.K.; Kessler, M. \& Cahill, T.M. 2002. Estimating species richness of tropical bird communities from rapid assessment data. The Auk, 119: 749-769.

ICMBio - Instituto Chico Mendes de Conservação da Biodiversidade. 2014. Lista de Espécies Ameaçadas -2014. Available at: www.icmbio.gov.br/ portal/biodiversidade/fauna-brasileira/lista-de-especies.html. Access in: 11/06/2015.

Kirwan, G.M.; Barnett, J.M. \& Minns, J. 2001. Significant ornithological observations from the Rio São Francisco Valley, Minas Gerais, Brazil, with notes on conservation and biogeography. Ararajuba, 9: 145-161.

Kirwan, G.M.; Barnett, J.M.; Vasconcelos, M.F.; Raposo, M.A.; D'Angelo-Neto, S. \& Roesler, I. 2004. Further comments on the avifauna of the middle São Francisco Valley, Minas Gerais, Brazil. Bulletin of the British Ornithologists' Club, 124: 207-220.

Lima, F.C.T. 1999. A range extension for the Caatinga Black-tyrant, Knipolegus franciscanus (Tyrannidae), a rare Brazilian endemic. Bulletin of the British Ornithologists' Club, 119: 270-271.

Lopes, L.E. 2009. Taxonomia, biogeografia e conservação das aves endêmicas do Cerrado. (Ph.D. Dissertation). Belo Horizonte, Universidade Federal de Minas Gerais.

Lopes, L.E.; D’Angelo-Neto, S.; Leite, L.O.; Moraes, L.L. \& Capurucho, J.M.G. 2010. Birds from Rio Pandeiros, southeastern Brazil: a wetland in an arid ecotone. Revista Brasileira de Ornitologia, 18: 267-282.

Lopes, L.E.; Maldonado-Coelho, M.; Hoffmann, D.; Luiz, E.R. \& D'Angelo Neto, S. 2008. Geographic distribution, habitat association, and conservation status of the Critically Endangered Minas Gerais Tyrannulet Phylloscartes roquettei. Bird Conservation International, 18: 53-62.

Lopes, L.E.; Vasconcelos, M.F. \& Gonzaga, L.P. 2017. A cryptic new species of hummingbird of the Campylopterus largipennis complex (Aves: Trochilidae). Zootaxa, 4268: 1-33.

Luiz, E.R.; Ribon, R.; Mattos, G.T. \& Moraes, L.L. 2006. Discovery of Minas Gerais Tyrannulet Phylloscartes roquettei in the Jequitinhonha Valley, north-east Minas Gerais, Brazil. Cotinga, 26: 84-86.

Mackinnon, S. \& Phillips, K. 1993. A field guide to the birds of Borneo, Sumatra, Java and Bali. Oxford, Oxford University Press. 491p.

MacLeod, R.; Herzog, S.K.; MacCormick, A.; Ewing, S.R.; Bryce, R. \& Evans, K.L. 2011. Rapid monitoring of species abundance for biodiversity conservation: consistency and reliability of the Mackinnon lists technique. Biological Conservation, 144: 1374-1381.

Marantz, C.A. 1997. Geographic variation of plumage patterns in the woodcreeper genus Dendrocolaptes (Dendrocolaptidae). Ornithological Monographs, 48: 399-429.

Marantz, C.A.; Aleixo, A.; Bevier, L.R. \& Patten, M.A. 2003. Family Dendrocolaptidae (woodcreepers). In: del Hoyo, J.; Elliott, A. \& Christie, D.A. (Eds.). Handbook of the birds of the world. Volume 8: Broadbills to tapaculos. Barcelona, Lynx Edicions. p. 358-447.

Martins, F.C. 2007. Estrutura de comunidades de aves em remanescentes de floresta estacional decidual na região do Vale do Rio Paranã - GO e TO. (Ph.D. Dissertation). Universidade de Brasília, Brasília.

Mattos, G.T.; Andrade, M.A. \& Freitas, M.V. 1991. Levantamento de aves silvestres na região noroeste de Minas Gerais. Revista SOM, 39: 26-29.

Mazzoni, L.G.; Perillo, A.; D’Angelo-Neto, S.; Vasconcelos, M.F. \& Santos, T. 2015. Additions to the avifauna of Unaí and Cabeceira Grande, northwest Minas Gerais. Cotinga, 37: 61-65.

Meyer de Schauensee, R. 1966. The species of birds of South America with their distribution. Narberth, Academy of Natural Sciences of Philadelphia. 577p.

Moreira-Lima, L. 2013. Aves da Mata Atlântica: riqueza, composição, status, endemismos e conservação. (M.Sc. Dissertation). Universidade de São Paulo, São Paulo, Brazil. 
Morrone, J.J. 2014. Biogeographical regionalisation of the Neotropical region. Zootaxa, 3782: 1-110.

Munsell. 2000. Soil color charts: revised washable edition. New York, Macbeth Division of Kollmorgen Corporation.

Olmos, F. 2005. Aves ameaçadas, prioridades e políticas de conservação no Brasil. Natureza \& Conservação, 3: 21-42.

Olmos, F. 2008. A new locality for Moustached Woodcreeper Xiphocolaptes falcirostris, Wagler's Woodcreeper Lepidocolaptes wagleri and Caatinga Black Tyrant Knipolegus franciscanus. Cotinga, 30: 87-89.

Olmos, F.; Girão e Silva, W.A. \& Albano, C.G. 2005. Aves em oito áreas de Caatinga no sul do Ceará e oeste de Pernambuco, nordeste do Brasil: composição, riqueza e similaridade. Papéis Avulsos de Zoologia, 45: 179-199.

Olmos, F.; Martuscelli, P. \& Silva e Silva, R. 1997. Distribution and dry-season ecology of Pfrimer's Conure Pyrrhura pfrimeri, with a reappraisal of Brazilian Pyrrhura "leucotis". Ornitología Neotropical, 8: 121-132.

Pacheco, J.F. 2004. As aves da Caatinga: uma análise histórica do conhecimento. In: Silva, J.M.C.; Tabarelli, M.; Fonseca, M.T. \& Lins, L.V. (Eds.). Biodiversidade da Caatinga: áreas e ações prioritárias para a conservação. Brasília, MMA. p. 189-250.

Pacheco, J.F. \& Olmos, F. 2006. As Aves do Tocantins 1: Região Sudeste. Revista Brasileira de Ornitologia, 14: 85-100.

Pennington, R.T.; Lavin, M. \& Oliveira-Filho, A.T. 2009. Woody plant diversity, evolution and ecology in the tropics: perspectives from seasonally dry tropical forests. Annual Review of Ecology, Evolution, and Systematics, 40: 437-457.

Pennington, R.T.; Lewis, G.P. \& Ratter, J.A. 2006. Neotropical savannas and dry forests: plant diversity, biogeography, and conservation. Oxford, Taylor \& Francis. 504p.

Pennington, R.T.; Prado, D.E. \& Pendry, C.A. 2000. Neotropical seasonally dry forests and Quaternary vegetation changes. Journal of Biogeography, 27: 261-273.

Piacentini, V.Q.; Aleixo, A.; Agne, C.E.; Maurício, G.N.; Pacheco, J.F.; Bravo, G.A.; Brito, G.R.R.; Naka, L.N.; Olmos, F.; Posso, S.; Silveira, L.F.; Betini, G.S.; Carrano, E.; Franz, I.; Lees, A.C.; Lima, L.M.; Pioli, D.; Schunck, F.; Amaral, F.R.; Bencke, G.A.; Cohn-Haft, M.; Figueiredo, L.F.A.; Straube, F.C. \& Cesari, E. 2015. Annotated checklist of the birds of Brazil by the Brazilian Ornithological Records Committee / Lista comentada das aves do Brasil pelo Comitê Brasileiro de Registros Ornitológicos. Revista Brasileira de Ornitologia, 23: 91-298.

Pinto, 0.M.0. 1938. Catalogo das aves do Brasil e lista dos exemplares que as representam no Museu Paulista. Revista do Museu Paulista, 22: 1-561.

Pinto, 0.M.0. 1952. Súmula histórica e sistemática da ornitologia de Minas Gerais. Arquivos de Zoologia, São Paulo, 8: 1-51.

Pinto, 0.M.0. 1978. Novo catálogo das aves do Brasil. Primeira parte. São Paulo, Empresa Gráfica da Revista dos Tribunais. 446p.

Pinto, 0.M.0. \& Camargo, E.A. 1961. Resultados ornitológicos de quatro recentes expedições do Departamento de Zoologia ao Nordeste do Brasil, com a descrição de seis novas subespécies. Arquivos de Zoologia do Estado de São Paulo, 11: 193-284.

Prado, D.E. \& Gibbs, P.E. 1993. Patterns of species distributions in the dry seasonal forest of South America. Annals of the Missouri Botanical Garden, 80: 902-927.

Raposo, M.A.; Mazar-Barnett, J.; Kirwan, G.M. \& Parrini, R. 2002. New data concerning the distribution, behaviour, ecology and taxonomic relationships of Minas Gerais Tyrannulet Phylloscartes roquettei. Bird Conservation International, 12: 241-253.

Rego, M.A.; Silveira, L.F.; Piacentini, V.Q.; Schunck, F.; Machado, É.; Pinheiro, R.T. \& Reis, E. 2011. As aves da Estação Ecológica Serra Geral do Tocantins, Centro do Brasil. Biota Neotropica, 11: 283-297.
Ribon, R. 2010. Amostragem de aves pelo método de listas de Mackinnon. In: Von Matter, S.; Straube, F.C.; Accordi, I.; Piacentini, V. \& Cândido-Jr., J.F. (Eds.). Ornitologia e conservação: ciência aplicada, técnicas de pesquisa e levantamento. Rio de Janeiro, Technical Books. p. 31-44.

Rizzini, C.T. 1997. Tratado de fitogeografia do Brasil: aspectos ecológicos, sociológicos e florísticos. Rio de Janeiro, Âmbito Cultural Edições. 747p.

Santos, R.M.; Oliveira-Filho, A.T.; Eisenlohr, P.V.; Queiroz, L.P.; Cardoso, D.B.O.S. \& Rodal, M.J.N. 2012. Identity and relationships of the Arboreal Caatinga among other floristic units of seasonally dry tropical forests (SDTFs) of north-eastern and Central Brazil. Ecology and Evolution, 2: 409-428.

Santos, S.S.; Fonseca-Neto, F.P.; Pacheco, J.F.; Parrini, R. \& Serpa, G.A. 2009. Primeiros registros de Phylloscartes roquettei Snethlage, 1928, na Bahia, nordeste do Brasil. Revista Brasileira de Ornitologia, 17: 217-219.

Short, L.L. 1972. Relationships among the four species of the superspecies Celeus elegans (Aves, Picidae). American Museum Novitates, 2487: 1-26.

Short, L.L. 1982. Woodpeckers of the world. Greenville, Delaware Museum of Natural History. 676p.

Sick, H. 1997. Ornitologia brasileira. Rio de Janeiro, Nova Fronteira. 862p.

Silva, C.A. 2015. WA1897112, Xiphocolaptes albicollis (Vieillot, 1818). Available at: www.wikiaves.com/1897112. Access in: 28/04/2017.

Silva, J.M.C. 1989. Análise biogeográfica da avifauna de florestas do interflúvio Araguaia-São Francisco. (M.Sc. Dissertation). Universidade de Brasília, Brasília.

Silva, J.M.C. 1995. Birds of the Cerrado region, South America. Steenstrupia, 21: 69-92.

Silva, J.M.C. 1997. Endemic bird species and conservation in the Cerrado region, South America. Biodiversity and Conservation, 6: 435-450.

Silva, J.M.C. \& Bates, J.M. 2002. Biogeographic patterns and conservation in the South American Cerrado: a tropical savanna hotspot. BioScience, 52: 225-233.

Silva, J.M.C. \& Oren, D.C. 1992. Notes on Knipolegus franciscanus Snethlage, 1928 (Aves: Tyrannidae), an endemism of central Brazilian dry forests. Goeldiana Zoologia, 16: 1-9.

Silva, J.M.C. \& Oren, D.C. 1997. Geographic variation and conservation of the Moustached Woodcreeper Xiphocolaptes falcirostris, an endemic and threatened species of north-eastern Brazil. Bird Conservation International, 7: 263-274.

Silva, J.M.C. \& Straube, F.C. 1996. Systematics and biogeography of Scaled Woodcreepers (Aves: Dendrocolaptidae). Studies on Neotropical Fauna and Environment, 31: 3-10.

Silva, J.M.C.; Sousa, M.C. \& Castelletti, C.H.M. 2004. Areas of endemism for passerine birds in the Atlantic forest, South America. Global Ecology and Biogeography, 13: 85-92.

Stattersfield, A.J.; Crosby, M.J.; Long, A.J. \& Wege, D.C. 1998. Endemic bird areas of the world: priorities for biodiversity conservation. Cambridge, BirdLife International. 846p.

Straube, F.C. \& Bianconi, G.V. 2002. Sobre a grandeza e a unidade utilizada para estimar esforço de captura com utilização de redes-de-neblina. Chiroptera Neotropical, 8: 150-152.

Tomotani, B.M. \& Silveira, L.F. 2016. A reassessment of the taxonomy of Crypturellus noctivagus (Wied, 1820). Revista Brasileira de Ornitologia, 24: 34-45.

Vasconcelos, M.F. \& D’Angelo-Neto, S. 2007. Padrões de distribuiç̧ão e conservação da avifauna na região central da Cadeia do Espinhaço e áreas adjacentes, Minas Gerais, Brasil. Cotinga, 28: 27-44.

Vasconcelos, M.F.; D'Angelo-Neto, S.; Kirwan, G.M.; Bornschein, M.R.; Diniz, M.G. \& Silva, J.F. 2006. Important ornithological records from Minas Gerais state, Brazil. Bulletin of the British Ornithologists' Club, 126: 212-238. 
Vasconcelos, M.F.; Diniz, M.G.; Guimarães, L. \& Garzon, B. 2008. An overlooked specimen of Minas Gerais Tyrannulet Phylloscartes roquettei. Cotinga, 29: 181-182.

Vasconcelos, M.F.; Souza, L.N.; Duca, C.; Pacheco, J.F.; Parrini, R.; Serpa, G.A.; Albano, C.; Abreu, C.R.M.; Santos, S.S. \& Fonseca-Neto, F.P. 2012. The avifauna of Brejinho das Ametistas, Bahia, Brazil: birds in a caatinga-cerrado transitional zone, with comments on taxonomy and biogeography. Revista Brasileira de Ornitologia, 20: 246-267.

Werneck, F.P. 2011. The diversification of eastern South American open vegetation biomes: historical biogeography and perspectives. Quaternary Science Reviews, 30: 1630-1648.

Werneck, F.P. \& Colli, G.R. 2006. The lizard assemblage from seasonally dry tropical forest enclaves in the Cerrado biome, Brazil, and its association with the Pleistocenic Arc. Journal of Biogeography, 33: 1983-1992.

Werneck, F.P.; Costa, G.C.; Colli, G.R.; Prado, D.E. \& Sites-Jr., J.W. 2011. Revisiting the historical distribution of Seasonally Dry Tropical Forests: new insights based on palaeodistribution modelling and palynological evidence. Global Ecology and Biogeography, 20: 272-288.

Wiki Aves. 2017. Pica-pau-ocráceo. Available at: www.wikiaves.com.br/picapau-ocraceo. Access in: 26/04/2017.

Willis, E.0. \& Oniki, Y. 1991. Avifaunal transects across the open zones of northern Minas Gerais, Brazil. Ararajuba, 2: 41-58.

Winkler, H. \& Christie, D.A. 2002. Family Picidae (woodpeckers). In: del Hoyo, J.; Elliott, A. \& Sargatal, J. (Eds.). Handbook of the birds of the world. Volume 7: Jacamars to woodpeckers. Barcelona, Lynx Edicions. p. 296-555. Winkler, H.; Christie, D.A. \& Nurney, D. 1995. Woodpeckers: a guide to the woodpeckers of the world. New York, Houghton Mifflin Company. 406p.

Zanella, F.C.V. 2010. Evolução da biota da diagonal de formações abertas secas da América do Sul. In: Carvalho, C.J.B. \& Almeida, E.A.B. (Eds.). Biogeografia da América do Sul: padrões e processos. São Paulo, Roca. p. $198-220$. 


\section{APPENDIX 1}

Analyzed specimens of woopeckers and woodcreepers that exhibit geographical variation in eastern Brazil. Institutions: Coleção Ornitológica do Centro de Coleções Taxonômicas da Universidade Federal de Minas Gerais (DZUFMG); Museu de História Natural e Jardim Botânico da Universidade Federal de Minas Gerais (MHNJBUFMG); Museu de Ciências Naturais da Pontifícia Universidade Católica de Minas Gerais (MCNA).

\section{Celeus ochraceus}

BRAZIL: Tocantins: Nova Olinda (1 9 MCNA 1795; 1 undetermined DZUFMG 6661). Bahia: Catinga do Moura (1 undetermined DZUFMG 2608). Minas Gerais: Riacho dos Machados (2 ơ MCNA 2522, MCNA 2763; 1 9 MCNA 2682); Campus Avançado (Unimontes), Janaúba (1 9 DZUFMG 3354); Curral de Pedras, Jequitaí (1 ơ MCNA 5057).

\section{Celeus flavescens}

BRAZIL: Minas Gerais: Fazenda Canabrava, Augusto de Lima (1 ơ MCNA 552); Parque do Rio Doce, Marliéria (1 9 DZUFMG 592); Mata do Cambraia, Perdões (1 ơ DZUFMG 3744). São Paulo: Itapetininga (1 \$ MHNJBUFMG 1022); Rio Guaratuba, Bertioga (2 ơ MHNJBUFMG 1014, MHNJBUFMG 1068; 3 9 MHNJBUFMG 1067, MHNJBUFMG 1114, MHNJBUFMG 1194).

\section{Sittasomus griseicapillus reiseri}

BRAZIL: Piauí: Malhadinha, Parnaguá (1 q MCNA 5386). Bahia: Catinga do Moura (1 undetermined DZUFMG 2800); Brejinho das Ametistas, Caetité (2 ơ DZUFMG 6137, DZUFMG 6138; 1 q DZUFMG 6136). Minas Gerais: Riacho dos Machados (4 ơ MCNA 2383, MCNA 2523, MCNA 2688, MCNA 3624; 1 \% MCNA 2681); Campus Avançado (Unimontes), Janaúba (5 ơ' DZUFMG 3393, DZUFMG 3394, DZUFMG 3427, DZUFMG 3428, DZUFMG 3430; 2 9 DZUFMG 3395, DZUFMG 3429).

\section{Sittasomus griseicapillus sylviellus}

BRAZIL: Minas Gerais: Rio Salinas, Salinas (1 q MCNA 207); Curral de Pedras, Jequitaí (2 ơ MCNA 4981, MCNA 5052; 1 ㅇ MCNA 4970); Fazenda do Sr. Onofre Sandinha, Leme do Prado (2 ơ DZUFMG 3568, DZUFMG 4010; 3 일UM 4011, DZUFMG 4013, DZUFMG 4014; 1 undetermined DZUFMG 4012); Fazenda Corredor, Bocaiúva (1 ơ DZUFMG 5292; 1 ९ DZUFMG 5291); Vau, Diamantina (1 ㅇ MCNA 1047); Fazenda Canabrava, Augusto de Lima (1 undetermined MCNA 663); Fazenda Jacaré-Riachão, Felixlândia (1 @ DZUFMG 4400); Serra da Ferrugem, Conceição do Mato Dentro (1 undetermined MCNA 4605); Parque do Rio Doce, Marliéria (1 ơ DZUFMG 651); APE Barreiro/COPASA, Belo Horizonte (1 q DZUFMG 3709); Mata do Jambreiro, Nova Lima (2 ơ DZUFMG 4431, DZUFMG 4432; 1 q DZUFMG 4433); Mina de Abóboras 2, Nova Lima (1 ơ MCNA 2194); Proximidades da Mina de Vargem Grande, Nova Lima (1 9 MCNA 4228); Fazenda Princesa da Serra, Itatiaiuçu (1 undetermined DZUFMG 6778); Mina de Abóboras 1, Rio Acima (1 o MCNA 2150); Nova Quartzito, Rio Acima (1 9 MCNA 3077); Fazenda Bocaina, Santa Bárbara (3 ơ DZUFMG 2861, DZUFMG 4842, MCNA 4536; 3 \% DZUFMG 5701, MCNA 4147, MCNA 4463; 3 undetermined DZUFMG 2555, DZUFMG 4463, MCNA 4148); Mina Córrego do Sítio, Santa Bárbara (2 o DZUFMG 6041, DZUFMG 6042); Taboões, Serra do Caraça, Santa Bárbara (4 ơ DZUFMG 4458, MCNA 2414, MCNA 4919, MCNA 4920; 2 9 MCNA 4899, MCNA 4903; 1 undetermined DZUFMG 3195); Trilha para a Capelinha, Serra do Caraça, Catas Altas (1 9 DZUFMG 5201); Serra do Caraça, Catas Altas (1 ơ DZUFMG 650; 2 9 DZUFMG 648, DZUFMG 649); Vertente Sul da Serra do Caraça, Mariana (1 ơ MCNA 1390; 1 @ MCNA 1406; 2 undetermined MCNA 1391, MCNA 1392); Mina de Fábrica Nova, CVRD, Mariana (1 ơ DZUFMG 5950; 1 undetermined DZUFMG 5949); Várzea do Lopes, Itabirito (1 ơ MCNA 3739); Rodeio de Baixo, Ouro Preto (1 9 MCNA 3744); Córrego Mãe D’Água, Congonhas (1 @ DZUFMG 7266); Mata do Cambraia, Perdões (2 ơ DZUFMG 3085, DZUFMG 3794; 1 9 DZUFMG 4153); Mata da Curva, Itumirim (2 ơ DZUFMG 3300, DZUFMG 4209); Fazenda Cachoeirão, Além Paraíba (1 ơ MCNA 2081); Sertão do Cantagalo, Gonçalves (1 ơ DZUFMG 5637; 2 9 DZUFMG 5313, DZUFMG 5638); Taperinha, Camanducaia (1 o' DZUFMG 5623). Espírito Santo: Santa Teresa (11 ơ DZUFMG 628, DZUFMG 629, DZUFMG 630, DZUFMG 631, DZUFMG 634, DZUFMG 635, DZUFMG 636, DZUFMG 637, DZUFMG 639, DZUFMG 640, DZUFMG 641; 5 9 DZUFMG 632, DZUFMG 633, DZUFMG 638, DZUFMG 643, DZUFMG 2806). São Paulo: Casa Grande, Salesópolis (2 o DZUFMG 644, DZUFMG 647; 2 9 DZUFMG 645, DZUFMG 646).

\section{Lepidocolaptes wagleri}

BRAZIL: Minas Gerais: Parque Estadual da Mata Seca, Manga (1 ơ DZUFMG 6010); Brejo do Amparo, Januária (1 o DZUFMG 7216; 1 undetermined DZUFMG 7215).

\section{Lepidocolaptes squamatus}

BRAZIL: Minas Gerais: Morro do Pilar (1 undetermined MCNA 4480); Área de influência do Mineroduto Minas-Rio, Pedra Bonita (1 o' MCNA 4079); Córrego do Andaime, Rio Acima (1 9 MCNA 3098); Serra do Caraça, Catas Altas (1 9 DZUFMG 686). Espírito Santo: Santa Teresa (2 ơ DZUFMG 676, DZUFMG 677; 4 9 DZUFMG 678, DZUFMG 679, DZUFMG 680, DZUFMG 681; 1 undetermined DZUFMG 682). Rio de Janeiro: Bem Posta, Três Rios (1 9 MCNA 2093). 
Lepidocolaptes wagleri / Lepidocolaptes squamatus (intermediate specimens)

BRAZIL: Bahia: Brejinho das Ametistas, Caetité (1 ơ DZUFMG 6571). Minas Gerais: Campus Avançado (Unimontes), Janaúba (2 o' DZUFMG 3406, DZUFMG 3407); Riacho dos Machados (2 ơ MCNA 2749, MCNA 3599; 2 9 MCNA 2521, MCNA 2679; 1 undetermined MCNA 2021); Rio São Miguel, Arinos (1 ơ DZUFMG 685); Fazenda Brejão, Brasilândia de Minas (1 undetermined DZUFMG 7152); Minas Novas (1 ơ DZUFMG 687); Curral de Pedras, Jequitaí (2 9 MCNA 4978, MCNA 5237); Fazenda Corredor, Bocaiúva (1 \& DZUFMG 5010).

\section{Dendrocolaptes platyrostris platyrostris}

BRAZIL: Minas Gerais: Sertão do Cantagalo, Gonçalves (2 ơ DZUFMG 5639, DZUFMG 5749; 1 q DZUFMG 5640). Espírito Santo: Santa Teresa (1 ơ DZUFMG 698). São Paulo: Casa Grande, Salesópolis (1 ơ DZUFMG 705); Itapetininga (1 우 DZUFMG 706).

\section{Dendrocolaptes platyrostris intermedius}

BRAZIL: Goiás: Margem esquerda do Rio Claro, Cachoeira Alta (1 ơ MCNA 1410); Fazenda Saloba, Montes Claros de Goiás (1 ơ DZUFMG 5402; 1 @ DZUFMG 5401). Minas Gerais: Fazenda Sertão, Itacarambi (1 ơ MCNA 5200); Rio São Miguel, Arinos (1 $\sigma^{\top}$ DZUFMG 702).

Dendrocolaptes platyrostris platyrostris / Dendrocolaptes platyrostris intermedius (intermediate specimens)

BRAZIL: Minas Gerais: Curral de Pedras, Jequitaí (3 ơ MCNA 5051, MCNA 5189, MCNA 5236; 1 \% MCNA 5235); Joaíma (1 ơ DZUFMG 704; 1 \% DZUFMG 703); Fazenda do Sr. Onofre Sandinha, Leme do Prado (1 ㅇ DZUFMG 3566); Fazenda Canabrava, Augusto de Lima (1 undetermined MCNA 206); Vau, Diamantina (1 ơ MCNA 1146); Cabeça de Boi, Itambé do Mato Dentro (1 o' DZUFMG 6340); Fazenda Faroeste, Iguatama (1 o DZUFMG 5018); Serra do Caraça, Catas Altas (3 ơ DZUFMG 699, DZUFMG 700, DZUFMG 701); Vertente Sul da Serra do Caraça, Mariana (1 ở DZUFMG 6537; 1 9 MCNA 1359).

\section{Xiphocolaptes albicollis bahiae}

BRAZIL: Minas Gerais: Mata do Seo Nozim, Francisco Sá (1 @ DZUFMG 3832); Curral de Pedras, Jequitaí (1 ơ MCNA 5204 ; 1 ㅇ MCNA 5203).

\section{Xiphocolaptes albicollis albicollis}

BRAZIL: Rio de Janeiro: Bem Posta, Três Rios (1 ơ MCNA 2061). São Paulo: Rio Guaratuba, Bertioga (1 ơ DZUFMG 622).

\section{Xiphocolaptes albicollis bahiae / Xiphocolaptes albicollis albicollis (intermediate specimens)}

BRAZIL: Minas Gerais: Conceição do Mato Dentro (1 ơ MCNA 2904; 1 q MCNA 2903); Captação de Água do Descoberto, Caeté (1 o DZUFMG 4903); Vertente Sul da Serra do Caraça, Mariana (1 ơ DZUFMG 6536). Espírito Santo: Santa Teresa (1 $\sigma^{\top}$ DZUFMG 625; 3 9 DZUFMG 623, DZUFMG 624, DZUFMG 626); Região de Chapéu, Domingos Martins (1 ơ MCNA 850). São Paulo: Casa Grande, Salesópolis (1 \& DZUFMG 621). 


\section{APPENDIX 2}

Birds recorded in Curral de Pedras, Jequitaí, Minas Gerais, Brazil. IFL: index of frequency in MacKinnon lists. Habitat: AE = aereal (in flight); $\mathrm{AC}=$ limestone outcrop; $\mathrm{FD}=$ dry forest; $\mathrm{HU}=$ area subject to human use (pastures and plantations); $M C=$ gallery forest.

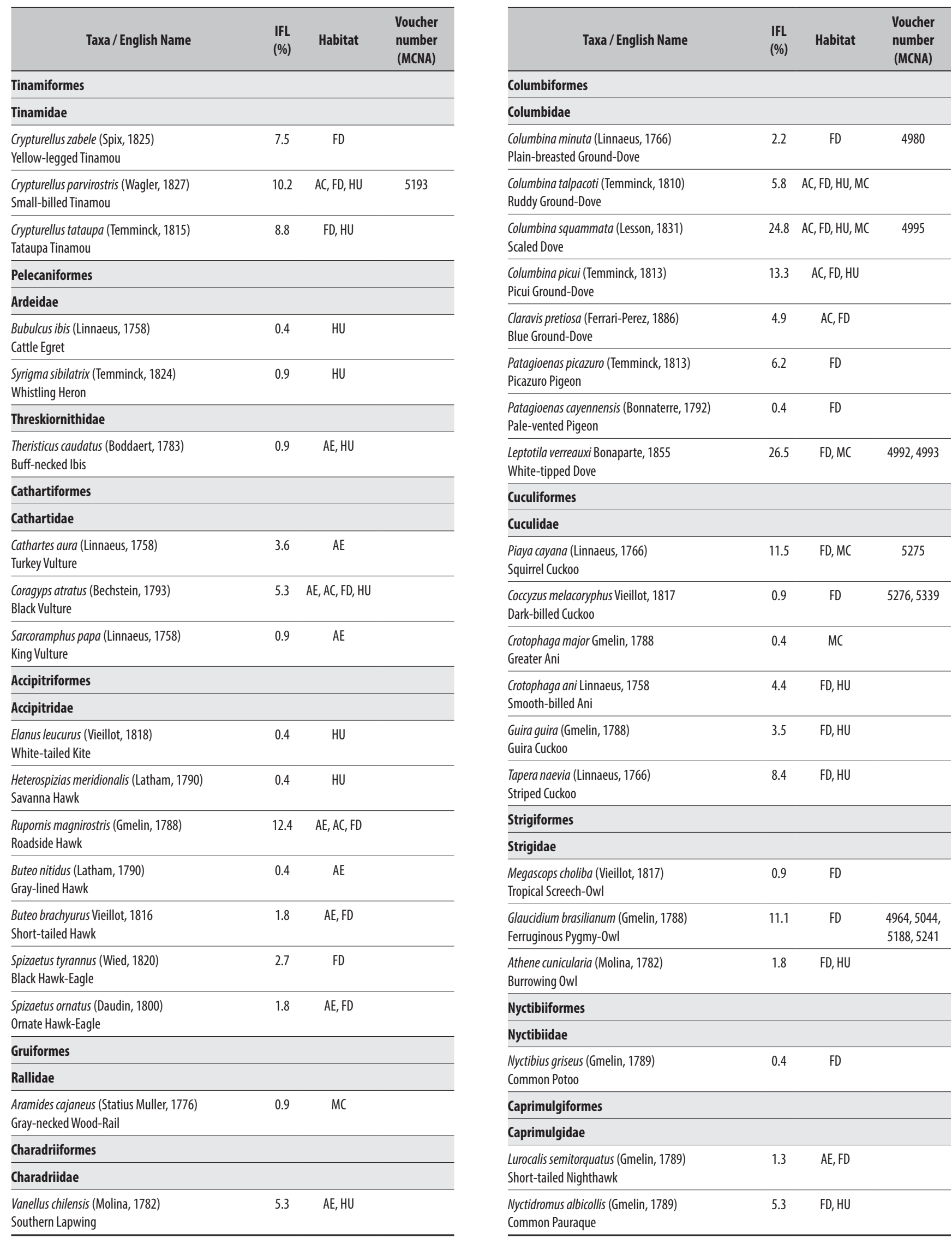




\begin{tabular}{|c|c|c|c|}
\hline Taxa / English Name & $\begin{array}{l}\text { IFL } \\
(\%)\end{array}$ & Habitat & $\begin{array}{l}\text { Voucher } \\
\text { number } \\
\text { (MCNA) }\end{array}$ \\
\hline \multicolumn{4}{|l|}{ Apodiformes } \\
\hline \multicolumn{4}{|l|}{ Apodidae } \\
\hline $\begin{array}{l}\text { Streptoprocne sp. } \\
\text { Swift }\end{array}$ & 5.3 & $\mathrm{AE}$ & \\
\hline $\begin{array}{l}\text { Chaetura meridionalis Hellmayr, } 1907 \\
\text { Sick's Swift }\end{array}$ & 1.8 & $\mathrm{AE}$ & \\
\hline \multicolumn{4}{|l|}{ Trochilidae } \\
\hline $\begin{array}{l}\text { Phaethornis pretrei (Lesson \& Delattre, 1839) } \\
\text { Planalto Hermit }\end{array}$ & 1.3 & $\mathrm{FD}, \mathrm{HU}$ & \\
\hline $\begin{array}{l}\text { Campylopterus calcirupicola Lopes, Vasconcelos \& } \\
\text { Gonzaga, } 2017 \\
\text { Dry-forest Sabrewing }\end{array}$ & 5.8 & $A C, F D$ & $\begin{array}{l}4977,5050, \\
5190\end{array}$ \\
\hline $\begin{array}{l}\text { Aphantochroa cirrochloris (Vieillot, 1818) } \\
\text { Sombre Hummingbird }\end{array}$ & 1.3 & FD & \\
\hline $\begin{array}{l}\text { Florisuga fusca (Vieillot, 1817) } \\
\text { Black Jacobin }\end{array}$ & 1.8 & $A C$ & \\
\hline $\begin{array}{l}\text { Colibri serrirostris (Vieillot, 1816) } \\
\text { White-vented Violetear }\end{array}$ & 0.4 & FD & \\
\hline $\begin{array}{l}\text { Chlorostilbon lucidus (Shaw, 1812) } \\
\text { Glittering-bellied Emerald }\end{array}$ & 5.8 & $A C, F D$ & 4987 \\
\hline $\begin{array}{l}\text { Thalurania furcata (Gmelin, 1788) } \\
\text { Fork-tailed Woodnymph }\end{array}$ & 4.0 & $A C, F D$ & $\begin{array}{l}5047,5048 \\
5340\end{array}$ \\
\hline $\begin{array}{l}\text { Amazilia versicolor (Vieillot, 1818) } \\
\text { Versicolored Emerald }\end{array}$ & 0.9 & FD & 4974,5305 \\
\hline $\begin{array}{l}\text { Amazilia fimbriata (Gmelin, 1788) } \\
\text { Glittering-throated Emerald }\end{array}$ & 9.7 & $\mathrm{AC}, \mathrm{FD}, \mathrm{HU}$ & $\begin{array}{l}4972,4986 \\
5249\end{array}$ \\
\hline $\begin{array}{l}\text { Heliomaster squamosus (Temminck, 1823) } \\
\text { Stripe-breasted Starthroat }\end{array}$ & 0.4 & FD & \\
\hline \multicolumn{4}{|l|}{ Trogoniformes } \\
\hline \multicolumn{4}{|l|}{ Trogonidae } \\
\hline $\begin{array}{l}\text { Trogon surrucura Vieillot, } 1817 \\
\text { Surucua Trogon }\end{array}$ & 10.2 & $\mathrm{FD}, \mathrm{MC}$ & $\begin{array}{l}4965,5181, \\
5182\end{array}$ \\
\hline \multicolumn{4}{|l|}{ Galbuliformes } \\
\hline \multicolumn{4}{|l|}{ Galbulidae } \\
\hline $\begin{array}{l}\text { Galbula ruficauda Cuvier, } 1816 \\
\text { Rufous-tailed Jacamar }\end{array}$ & 0.9 & MC & \\
\hline \multicolumn{4}{|l|}{ Bucconidae } \\
\hline $\begin{array}{l}\text { Nystalus maculatus (Gmelin, 1788) } \\
\text { Spot-backed Puffbird }\end{array}$ & 4.9 & FD & \\
\hline \multicolumn{4}{|l|}{ Piciformes } \\
\hline \multicolumn{4}{|l|}{ Ramphastidae } \\
\hline $\begin{array}{l}\text { Ramphastos toco Statius Muller, } 1776 \\
\text { Toco Toucan }\end{array}$ & 1.3 & $\mathrm{FD}, \mathrm{HU}$ & \\
\hline \multicolumn{4}{|l|}{ Picidae } \\
\hline $\begin{array}{l}\text { Picumnus cf. albosquamatus d'Orbigny, } 1840 \\
\text { White-wedged Piculet }\end{array}$ & 1.8 & $\mathrm{FD}, \mathrm{MC}$ & \\
\hline $\begin{array}{l}\text { Melanerpes candidus }(0 \mathrm{tto}, 1796) \\
\text { White Woodpecker }\end{array}$ & 0.9 & $A C, F D$ & \\
\hline $\begin{array}{l}\text { Veniliornis passerinus (Linnaeus, 1766) } \\
\text { Little Woodpecker }\end{array}$ & 11.1 & $A C, F D$ & 5041 \\
\hline $\begin{array}{l}\text { Piculus chrysochloros (Vieillot, 1818) } \\
\text { Golden-green Woodpecker }\end{array}$ & 1.8 & FD & \\
\hline $\begin{array}{l}\text { Colaptes melanochloros (Gmelin, 1788) } \\
\text { Green-barred Woodpecker }\end{array}$ & 5.3 & $A C, F D$ & \\
\hline
\end{tabular}

\begin{tabular}{|c|c|c|c|}
\hline Taxa / English Name & $\begin{array}{l}\text { IFL } \\
(\%)\end{array}$ & Habitat & $\begin{array}{l}\text { Voucher } \\
\text { number } \\
\text { (MCNA) }\end{array}$ \\
\hline $\begin{array}{l}\text { Colaptes campestris (Vieillot, 1818) } \\
\text { Campo Flicker }\end{array}$ & 0.4 & HU & \\
\hline $\begin{array}{l}\text { Celeus ochraceus (Spix, 1824) } \\
\text { Ochre-backed Woodpecker }\end{array}$ & 4.4 & FD & 5057 \\
\hline $\begin{array}{l}\text { Dryocopus lineatus (Linnaeus, 1766) } \\
\text { Lineated Woodpecker }\end{array}$ & 2.2 & FD & \\
\hline $\begin{array}{l}\text { Campephilus melanoleucos (Gmelin, 1788) } \\
\text { Crimson-crested Woodpecker }\end{array}$ & 3.5 & $A E, F D$ & \\
\hline \multicolumn{4}{|l|}{ Cariamiformes } \\
\hline \multicolumn{4}{|l|}{ Cariamidae } \\
\hline $\begin{array}{l}\text { Cariama cristata (Linnaeus, 1766) } \\
\text { Red-legged Seriema }\end{array}$ & 11.9 & $A C, F D, H U$ & \\
\hline \multicolumn{4}{|l|}{ Falconiformes } \\
\hline \multicolumn{4}{|l|}{ Falconidae } \\
\hline $\begin{array}{l}\text { Caracara plancus (Miller, 1777) } \\
\text { Southern Caracara }\end{array}$ & 1.8 & $\mathrm{AE}, \mathrm{AC}, \mathrm{FD}, \mathrm{HU}$ & \\
\hline $\begin{array}{l}\text { Milvago chimachima (Vieillot, 1816) } \\
\text { Yellow-headed Caracara }\end{array}$ & 4.0 & $A E, F D$ & \\
\hline $\begin{array}{l}\text { Herpetotheres cachinnans (Linnaeus, 1758) } \\
\text { Laughing Falcon }\end{array}$ & 3.5 & FD & \\
\hline $\begin{array}{l}\text { Micrastur semitorquatus (Vieillot, 1817) } \\
\text { Collared Forest-Falcon }\end{array}$ & 4.0 & FD & \\
\hline $\begin{array}{l}\text { Falco femoralis Temminck, } 1822 \\
\text { Aplomado Falcon }\end{array}$ & 0.4 & FD & \\
\hline \multicolumn{4}{|l|}{ Psittaciformes } \\
\hline \multicolumn{4}{|l|}{ Psittacidae } \\
\hline $\begin{array}{l}\text { Diopsittaca nobilis (Linnaeus, 1758) } \\
\text { Red-shouldered Macaw }\end{array}$ & 0.9 & $\mathrm{AE}$ & \\
\hline $\begin{array}{l}\text { Psittacara leucophthalmus (Statius Muller, 1776) } \\
\text { White-eyed Parakeet }\end{array}$ & 8.0 & $A E, A C, F D$ & \\
\hline $\begin{array}{l}\text { Aratinga auricapillus (Kuhl, 1820) } \\
\text { Golden-capped Parakeet }\end{array}$ & 19.0 & $A E, A C, F D$ & 5185 \\
\hline $\begin{array}{l}\text { Eupsittula cactorum (Kuhl, 1820) } \\
\text { Cactus Parakeet }\end{array}$ & 3.1 & $A E, F D$ & \\
\hline $\begin{array}{l}\text { Forpus xanthopterygius (Spix, 1824) } \\
\text { Blue-winged Parrotlet }\end{array}$ & 6.2 & $\begin{array}{c}\mathrm{AE}, \mathrm{AC}, \mathrm{FD} \\
\mathrm{HU}, \mathrm{MC}\end{array}$ & \\
\hline $\begin{array}{l}\text { Brotogeris chiriri (Vieillot, 1818) } \\
\text { Yellow-chevroned Parakeet }\end{array}$ & 26.5 & $\mathrm{AE}, \mathrm{AC}, \mathrm{FD}, \mathrm{HU}$ & $\begin{array}{c}5040,5184, \\
5231,5232, \\
5233,5234\end{array}$ \\
\hline $\begin{array}{l}\text { Pionus maximiliani (Kuhl, 1820) } \\
\text { Scaly-headed Parrot }\end{array}$ & 2.2 & $\mathrm{AE}$ & \\
\hline \multicolumn{4}{|l|}{ Passeriformes } \\
\hline \multicolumn{4}{|l|}{ Thamnophilidae } \\
\hline $\begin{array}{l}\text { Myrmorchilus strigilatus (Wied, 1831) } \\
\text { Stripe-backed Antbird }\end{array}$ & 13.3 & FD & \\
\hline $\begin{array}{l}\text { Formicivora melanogaster Pelzeln, } 1868 \\
\text { Black-bellied Antwren }\end{array}$ & 13.7 & $\mathrm{FD}, \mathrm{MC}$ & 5196 \\
\hline $\begin{array}{l}\text { Herpsilochmus atricapillus Pelzeln, } 1868 \\
\text { Black-capped Antwren }\end{array}$ & 8.0 & $\mathrm{FD}, \mathrm{MC}$ & \\
\hline $\begin{array}{l}\text { Thamnophilus capistratus Lesson, } 1840 \\
\text { Caatinga Antshrike }\end{array}$ & 2.2 & $\mathrm{FD}, \mathrm{MC}$ & \\
\hline $\begin{array}{l}\text { Thamnophilus pelzelni Hellmayr, } 1924 \\
\text { Planalto Slaty-Antshrike }\end{array}$ & 25.2 & $\mathrm{FD}, \mathrm{MC}$ & $\begin{array}{c}4963,5238 \\
5239,5247 \\
5252\end{array}$ \\
\hline $\begin{array}{l}\text { Taraba major (Vieillot, 1816) } \\
\text { Great Antshrike }\end{array}$ & 2.7 & $\mathrm{FD}, \mathrm{MC}$ & \\
\hline
\end{tabular}




\begin{tabular}{|c|c|c|c|}
\hline Taxa / English Name & $\begin{array}{l}\text { IFL } \\
(\%)\end{array}$ & Habitat & $\begin{array}{l}\text { Voucher } \\
\text { number } \\
\text { (MCNA) }\end{array}$ \\
\hline \multicolumn{4}{|l|}{ Dendrocolaptidae } \\
\hline $\begin{array}{l}\text { Sittasomus griseicapillus (Vieillot, 1818) } \\
\text { Olivaceous Woodcreeper }\end{array}$ & 12.8 & FD & $\begin{array}{l}4970,4981 \\
5052\end{array}$ \\
\hline $\begin{array}{l}\text { Campylorhamphus trochilirostris (Lichtenstein, 1820) } \\
\text { Red-billed Scythebill }\end{array}$ & 0.4 & FD & \\
\hline $\begin{array}{l}\text { Lepidocolaptes angustirostris (Vieillot, 1818) } \\
\text { Narrow-billed Woodcreeper }\end{array}$ & 0.9 & $\mathrm{FD}, \mathrm{HU}$ & \\
\hline $\begin{array}{l}\text { Lepidocolaptes cf. squamatus (Lichtenstein, 1822) } \\
\text { Scaled Woodcreeper }\end{array}$ & 19.5 & $\mathrm{FD}, \mathrm{MC}$ & 4978,5237 \\
\hline $\begin{array}{l}\text { Dendrocolaptes platyrostris Spix, } 1825 \\
\text { Planalto Woodcreeper }\end{array}$ & 6.2 & $\mathrm{FD}, \mathrm{MC}$ & $\begin{array}{l}5051,5189, \\
5235,5236\end{array}$ \\
\hline $\begin{array}{l}\text { Xiphocolaptes albicollis (Vieillot, 1818) } \\
\text { White-throated Woodcreeper }\end{array}$ & 6.2 & FD & 5203,5204 \\
\hline \multicolumn{4}{|l|}{ Furnariidae } \\
\hline $\begin{array}{l}\text { Furnarius figulus (Lichtenstein, 1823) } \\
\text { Wing-banded Hornero }\end{array}$ & 0.4 & MC & \\
\hline $\begin{array}{l}\text { Furnarius leucopus Swainson, } 1838 \\
\text { Pale-legged Hornero }\end{array}$ & 10.2 & $\mathrm{FD}, \mathrm{HU}, \mathrm{MC}$ & 5058 \\
\hline $\begin{array}{l}\text { Furnarius rufus (Gmelin, 1788) } \\
\text { Rufous Hornero }\end{array}$ & 4.9 & $\mathrm{FD}, \mathrm{HU}$ & \\
\hline $\begin{array}{l}\text { Phacellodomus rufifrons (Wied, 1821) } \\
\text { Rufous-fronted Thornbird }\end{array}$ & 2.7 & $\mathrm{FD}, \mathrm{HU}$ & \\
\hline $\begin{array}{l}\text { Schoeniophylax phryganophilus (Vieillot, 1817) } \\
\text { Chotoy Spinetail }\end{array}$ & 0.9 & $\mathrm{FD}, \mathrm{HU}$ & \\
\hline $\begin{array}{l}\text { Synallaxis frontalis Pelzeln, } 1859 \\
\text { Sooty-fronted Spinetail }\end{array}$ & 18.1 & $\mathrm{FD}, \mathrm{HU}, \mathrm{MC}$ & 5244 \\
\hline $\begin{array}{l}\text { Synallaxis albescens Temminck, } 1823 \\
\text { Pale-breasted Spinetail }\end{array}$ & 0.4 & HU & \\
\hline $\begin{array}{l}\text { Synallaxis scutata Sclater, } 1859 \\
\text { Ochre-cheeked Spinetail }\end{array}$ & 3.5 & FD & 4969,5197 \\
\hline \multicolumn{4}{|l|}{ Onychorhynchidae } \\
\hline $\begin{array}{l}\text { Myiobius atricaudus Lawrence, } 1863 \\
\text { Black-tailed Flycatcher }\end{array}$ & 0.4 & FD & \\
\hline \multicolumn{4}{|l|}{ Tityridae } \\
\hline $\begin{array}{l}\text { Tityra inquisitor (Lichtenstein, 1823) } \\
\text { Black-crowned Tityra }\end{array}$ & 3.1 & FD & \\
\hline $\begin{array}{l}\text { Pachyramphus viridis (Vieillot, 1816) } \\
\text { Green-backed Becard }\end{array}$ & 1.3 & $\mathrm{FD}, \mathrm{HU}$ & \\
\hline $\begin{array}{l}\text { Pachyramphus polychopterus (Vieillot, 1818) } \\
\text { White-winged Becard }\end{array}$ & 4.0 & FD & \\
\hline \multicolumn{4}{|l|}{ Rhynchocyclidae } \\
\hline $\begin{array}{l}\text { Leptopogon amaurocephalus Tschudi, } 1846 \\
\text { Sepia-capped Flycatcher }\end{array}$ & 4.4 & FD & 5266 \\
\hline $\begin{array}{l}\text { Tolmomyias sulphurescens (Spix, 1825) } \\
\text { Yellow-olive Flycatcher }\end{array}$ & 5.3 & $\mathrm{FD}, \mathrm{MC}$ & 4979,5267 \\
\hline $\begin{array}{l}\text { Tolmomyias flaviventris (Wied, 1831) } \\
\text { Yellow-breasted Flycatcher }\end{array}$ & 14.2 & FD & \\
\hline $\begin{array}{l}\text { Todirostrum cinereum (Linnaeus, 1766) } \\
\text { Common Tody-Flycatcher }\end{array}$ & 1.3 & $\mathrm{FD}, \mathrm{HU}, \mathrm{MC}$ & \\
\hline $\begin{array}{l}\text { Hemitriccus margaritaceiventer (d'0rbigny \& } \\
\text { Lafresnaye, 1837) } \\
\text { Pearly-vented Tody-tyrant }\end{array}$ & 19.5 & $A C, F D, M C$ & 4975,4988 \\
\hline \multicolumn{4}{|l|}{ Tyrannidae } \\
\hline $\begin{array}{l}\text { Hirundinea ferruginea (Gmelin, 1788) } \\
\text { Cliff Flycatcher }\end{array}$ & 8.0 & $A C, F D$ & \\
\hline $\begin{array}{l}\text { Camptostoma obsoletum (Temminck, 1824) } \\
\text { Southern Beardless-Tyrannulet }\end{array}$ & 6.6 & FD & \\
\hline
\end{tabular}

\begin{tabular}{|c|c|c|c|}
\hline Taxa / English Name & $\begin{array}{l}\text { IFL } \\
(\%)\end{array}$ & Habitat & $\begin{array}{l}\text { Voucher } \\
\text { number } \\
\text { (MCNA) }\end{array}$ \\
\hline $\begin{array}{l}\text { Elaenia flavogaster (Thunberg, 1822) } \\
\text { Yellow-bellied Elaenia }\end{array}$ & 0.4 & $A C$ & \\
\hline $\begin{array}{l}\text { Elaenia cf. mesoleuca (Deppe, 1830) } \\
\text { Olivaceous Elaenia }\end{array}$ & 0.4 & FD & 4967 \\
\hline $\begin{array}{l}\text { Suiriri suiriri (Vieillot, 1818) } \\
\text { Suiriri Flycatcher }\end{array}$ & 0.4 & HU & \\
\hline $\begin{array}{l}\text { Myiopagis caniceps (Swainson, 1835) } \\
\text { Gray Elaenia }\end{array}$ & 9.7 & $\mathrm{FD}, \mathrm{MC}$ & \\
\hline $\begin{array}{l}\text { Myiopagis viridicata (Vieillot, 1817) } \\
\text { Greenish Elaenia }\end{array}$ & 6.6 & FD & $\begin{array}{l}5242,5243 \\
5250\end{array}$ \\
\hline $\begin{array}{l}\text { Phaeomyias murina (Spix, 1825) } \\
\text { Mouse-colored Tyrannulet }\end{array}$ & 1.8 & FD & \\
\hline $\begin{array}{l}\text { Phyllomyias fasciatus (Thunberg, 1822) } \\
\text { Planalto Tyrannulet }\end{array}$ & 3.1 & FD & \\
\hline $\begin{array}{l}\text { Myiarchus ferox (Gmelin, 1789) } \\
\text { Short-crested Flycatcher }\end{array}$ & 2.7 & FD & \\
\hline $\begin{array}{l}\text { Myiarchus tyrannulus (Statius Muller, 1776) } \\
\text { Brown-crested Flycatcher }\end{array}$ & 19.9 & $A C, F D, M C$ & 5186 \\
\hline $\begin{array}{l}\text { Sirystes sibilator (Vieillot, 1818) } \\
\text { Sibilant Sirystes }\end{array}$ & 8.4 & FD & \\
\hline $\begin{array}{l}\text { Casiornis rufus (Vieillot, 1816) } \\
\text { Rufous Casiornis }\end{array}$ & 6.2 & FD & 4968,5245 \\
\hline $\begin{array}{l}\text { Pitangus sulphuratus (Linnaeus, 1766) } \\
\text { Great Kiskadee }\end{array}$ & 21.7 & $A C, F D, H U, M C$ & \\
\hline $\begin{array}{l}\text { Machetornis rixosa (Vieillot, 1819) } \\
\text { Cattle Tyrant }\end{array}$ & 0.4 & HU & \\
\hline $\begin{array}{l}\text { Myiodynastes maculatus (Statius Muller, 1776) } \\
\text { Streaked Flycatcher }\end{array}$ & 15.0 & $A C, F D$ & 5192 \\
\hline $\begin{array}{l}\text { Megarynchus pitangua (Linnaeus, 1766) } \\
\text { Boat-billed Flycatcher }\end{array}$ & 16.4 & $\mathrm{AC}, \mathrm{FD}, \mathrm{HU}$ & \\
\hline $\begin{array}{l}\text { Myiozetetes similis (Spix, 1825) } \\
\text { Social Flycatcher }\end{array}$ & 13.3 & $A C, F D, H U, M C$ & \\
\hline $\begin{array}{l}\text { Tyrannus melancholicus Vieillot, } 1819 \\
\text { Tropical Kingbird }\end{array}$ & 3.5 & $\mathrm{FD}, \mathrm{HU}$ & \\
\hline $\begin{array}{l}\text { Tyrannus savana Daudin, } 1802 \\
\text { Fork-tailed Flycatcher }\end{array}$ & 0.4 & FD & \\
\hline $\begin{array}{l}\text { Griseotyrannus aurantioatrocristatus (d'Orbigny \& } \\
\text { Lafresnaye, 1837) } \\
\text { Crowned Slaty Flycatcher }\end{array}$ & 0.4 & FD & \\
\hline $\begin{array}{l}\text { Empidonomus varius (Vieillot, 1818) } \\
\text { Variegated Flycatcher }\end{array}$ & 2.7 & FD & \\
\hline $\begin{array}{l}\text { Colonia colonus (Vieillot, 1818) } \\
\text { Long-tailed Tyrant }\end{array}$ & 0.4 & FD & \\
\hline $\begin{array}{l}\text { Myiophobus fasciatus (Statius Muller, 1776) } \\
\text { Bran-colored Flycatcher }\end{array}$ & 1.3 & $\mathrm{FD}, \mathrm{HU}$ & \\
\hline $\begin{array}{l}\text { Fluvicola nengeta (Linnaeus, 1766) } \\
\text { Masked Water-Tyrant }\end{array}$ & 1.3 & HU, MC & \\
\hline $\begin{array}{l}\text { Cnemotriccus fuscatus (Wied, 1831) } \\
\text { Fuscous Flycatcher }\end{array}$ & 7.1 & FD & 5240 \\
\hline $\begin{array}{l}\text { Lathrotriccus euleri (Cabanis, 1868) } \\
\text { Euler's Flycatcher }\end{array}$ & 6.2 & FD & \\
\hline $\begin{array}{l}\text { Contopus cinereus (Spix, 1825) } \\
\text { Tropical Pewee }\end{array}$ & 4.4 & FD & \\
\hline $\begin{array}{l}\text { Knipolegus franciscanus Snethlage, } 1928 \\
\text { Caatinga Black-Tyrant }\end{array}$ & 15.0 & $A C, F D, M C$ & $\begin{array}{l}4966,5049, \\
5055,5180 \\
5191,5227 \\
5230,5268\end{array}$ \\
\hline
\end{tabular}




\begin{tabular}{|c|c|c|c|}
\hline Taxa / English Name & $\begin{array}{l}\text { IFL } \\
(\%)\end{array}$ & Habitat & $\begin{array}{l}\text { Voucher } \\
\text { number } \\
\text { (MCNA) }\end{array}$ \\
\hline \multicolumn{4}{|l|}{ Vireonidae } \\
\hline $\begin{array}{l}\text { Cyclarhis gujanensis (Gmelin, 1789) } \\
\text { Rufous-browed Peppershrike }\end{array}$ & 15.9 & $\mathrm{FD}, \mathrm{MC}$ & $\begin{array}{l}5043,5246 \\
5265\end{array}$ \\
\hline $\begin{array}{l}\text { Hylophilus amaurocephalus (Nordmann, 1835) } \\
\text { Gray-eyed Greenlet }\end{array}$ & 0.9 & FD & \\
\hline $\begin{array}{l}\text { Vireo chivi (Vieillot, 1817) } \\
\text { Chivi Vireo }\end{array}$ & 0.9 & FD & \\
\hline \multicolumn{4}{|l|}{ Corvidae } \\
\hline $\begin{array}{l}\text { Cyanocorax cyanopogon (Wied, 1821) } \\
\text { White-naped Jay }\end{array}$ & 14.2 & FD, HU, MC & 4973 \\
\hline \multicolumn{4}{|l|}{ Hirundinidae } \\
\hline $\begin{array}{l}\text { Pygochelidon cyanoleuca (Vieillot, 1817) } \\
\text { Blue-and-white Swallow }\end{array}$ & 6.6 & $\mathrm{AE}$ & \\
\hline $\begin{array}{l}\text { Progne tapera (Vieillot, 1817) } \\
\text { Brown-chested Martin }\end{array}$ & 0.4 & FD & \\
\hline \multicolumn{4}{|l|}{ Troglodytidae } \\
\hline $\begin{array}{l}\text { Troglodytes musculus Naumann, } 1823 \\
\text { Southern House Wren }\end{array}$ & 22.1 & $\mathrm{AC}, \mathrm{FD}, \mathrm{HU}, \mathrm{MC}$ & $\begin{array}{l}4984,5229 \\
5306\end{array}$ \\
\hline $\begin{array}{l}\text { Cantorchilus leucotis (Lafresnaye, 1845) } \\
\text { Buff-breasted Wren }\end{array}$ & 2.7 & $\mathrm{FD}, \mathrm{MC}$ & \\
\hline \multicolumn{4}{|l|}{ Polioptilidae } \\
\hline $\begin{array}{l}\text { Polioptila plumbea (Gmelin, 1788) } \\
\text { Tropical Gnatcatcher }\end{array}$ & 4.9 & $A C, F D$ & \\
\hline \multicolumn{4}{|l|}{ Turdidae } \\
\hline $\begin{array}{l}\text { Turdus leucomelas Vieillot, } 1818 \\
\text { Pale-breasted Thrush }\end{array}$ & 13.3 & $A C, F D$ & 4991 \\
\hline $\begin{array}{l}\text { Turdus rufiventris Vieillot, } 1818 \\
\text { Rufous-bellied Thrush }\end{array}$ & 0.4 & FD & 5046 \\
\hline $\begin{array}{l}\text { Turdus amaurochalinus Cabanis, } 1850 \\
\text { Creamy-bellied Thrush }\end{array}$ & 4.9 & FD & 5187 \\
\hline $\begin{array}{l}\text { Turdus albicollis Vieillot, } 1818 \\
\text { White-necked Thrush }\end{array}$ & 8.4 & FD & $\begin{array}{l}5045,5056 \\
5228\end{array}$ \\
\hline \multicolumn{4}{|l|}{ Passerellidae } \\
\hline $\begin{array}{l}\text { Arremon flavirostris Swainson, } 1838 \\
\text { Saffron-billed Sparrow }\end{array}$ & 0.4 & MC & \\
\hline \multicolumn{4}{|l|}{ Parulidae } \\
\hline $\begin{array}{l}\text { Basileuterus culicivorus (Deppe, 1830) } \\
\text { Golden-crowned Warbler }\end{array}$ & 6.2 & $\mathrm{FD}, \mathrm{MC}$ & $\begin{array}{l}4971,5054 \\
5059\end{array}$ \\
\hline $\begin{array}{l}\text { Myiothlypis flaveola Baird, } 1865 \\
\text { Flavescent Warbler }\end{array}$ & 23.0 & $\mathrm{FD}, \mathrm{MC}$ & $\begin{array}{l}5053,5248 \\
5251\end{array}$ \\
\hline \multicolumn{4}{|l|}{ Icteridae } \\
\hline $\begin{array}{l}\text { Psarocolius decumanus (Pallas, 1769) } \\
\text { Crested Oropendola }\end{array}$ & 4.4 & FD & \\
\hline
\end{tabular}

\begin{tabular}{|c|c|c|c|}
\hline Taxa / English Name & $\begin{array}{l}\text { IFL } \\
(\%)\end{array}$ & Habitat & $\begin{array}{l}\text { Voucher } \\
\text { number } \\
\text { (MCNA) }\end{array}$ \\
\hline $\begin{array}{l}\text { Icterus pyrrhopterus (Vieillot, 1819) } \\
\text { Variable Oriole }\end{array}$ & 3.1 & $A C, F D, M C$ & \\
\hline $\begin{array}{l}\text { Icterus jamacaii (Gmelin, 1788) } \\
\text { Campo Troupial }\end{array}$ & 20.8 & $\mathrm{FD}, \mathrm{HU}$ & 4982 \\
\hline $\begin{array}{l}\text { Gnorimopsar chopi (Vieillot, 1819) } \\
\text { Chopi Blackbird }\end{array}$ & 1.3 & HU & \\
\hline $\begin{array}{l}\text { Molothrus bonariensis (Gmelin, 1789) } \\
\text { Shiny Cowbird }\end{array}$ & 1.3 & $\mathrm{AC}, \mathrm{FD}, \mathrm{HU}$ & \\
\hline \multicolumn{4}{|l|}{ Thraupidae } \\
\hline $\begin{array}{l}\text { Paroaria dominicana (Linnaeus, 1758) } \\
\text { Red-cowled Cardinal }\end{array}$ & 0.4 & FD & \\
\hline $\begin{array}{l}\text { Tangara sayaca (Linnaeus, 1766) } \\
\text { Sayaca Tanager }\end{array}$ & 14.6 & $A C, F D$ & \\
\hline $\begin{array}{l}\text { Tangara cayana (Linnaeus, 1766) } \\
\text { Burnished-buff Tanager }\end{array}$ & 2.2 & $A C, F D, H U$ & \\
\hline $\begin{array}{l}\text { Nemosia pileata (Boddaert, 1783) } \\
\text { Hooded Tanager }\end{array}$ & 1.8 & FD & \\
\hline $\begin{array}{l}\text { Compsothraupis loricata (Lichtenstein, 1819) } \\
\text { Scarlet-throated Tanager }\end{array}$ & 10.2 & $\mathrm{AC}, \mathrm{FD}, \mathrm{HU}$ & \\
\hline $\begin{array}{l}\text { Conirostrum speciosum (Temminck, 1824) } \\
\text { Chestnut-vented Conebill }\end{array}$ & 4.0 & FD & \\
\hline $\begin{array}{l}\text { Hemithraupis guira (Linnaeus, 1766) } \\
\text { Guira Tanager }\end{array}$ & 8.4 & $\mathrm{FD}, \mathrm{MC}$ & \\
\hline $\begin{array}{l}\text { Volatinia jacarina (Linnaeus, 1766) } \\
\text { Blue-black Grassquit }\end{array}$ & 2.7 & $\mathrm{FD}, \mathrm{HU}$ & 4983 \\
\hline $\begin{array}{l}\text { Coryphospingus pileatus (Wied, 1821) } \\
\text { Pileated Finch }\end{array}$ & 12.8 & $A C, F D$ & 4976,4985 \\
\hline $\begin{array}{l}\text { Tachyphonus rufus (Boddaert, 1783) } \\
\text { White-lined Tanager }\end{array}$ & 4.0 & $A C, F D, M C$ & 5042,5183 \\
\hline $\begin{array}{l}\text { Coereba flaveola (Linnaeus, 1758) } \\
\text { Bananaquit }\end{array}$ & 0.4 & FD & \\
\hline $\begin{array}{l}\text { Sporophila lineola (Linnaeus, 1758) } \\
\text { Lined Seedeater }\end{array}$ & 0.4 & FD & \\
\hline $\begin{array}{l}\text { Sporophila nigricollis (Vieillot, 1823) } \\
\text { Yellow-bellied Seedeater }\end{array}$ & 2.2 & $\mathrm{FD}, \mathrm{MC}$ & \\
\hline $\begin{array}{l}\text { Saltatricula atricollis (Vieillot, 1817) } \\
\text { Black-throated Saltator }\end{array}$ & 0.9 & HU & \\
\hline $\begin{array}{l}\text { Saltator similis d'Orbigny \& Lafresnaye, } 1837 \\
\text { Green-winged Saltator }\end{array}$ & 1.3 & FD & \\
\hline Cardinalidae & & & \\
\hline $\begin{array}{l}\text { Cyanoloxia brissonii (Lichtenstein, 1823) } \\
\text { Ultramarine Grosbeak }\end{array}$ & 3.1 & FD & \\
\hline Fringillidae & & & \\
\hline $\begin{array}{l}\text { Euphonia chlorotica (Linnaeus, 1766) } \\
\text { Purple-throated Euphonia }\end{array}$ & 7.1 & $\mathrm{FD}, \mathrm{HU}$ & \\
\hline
\end{tabular}

